\title{
Impact of root exudates and plant defense signaling on bacterial communities in the rhizosphere. A review
}

\author{
Rogier F. Doornbos • Leendert Cornelis van Loon • \\ Peter A. H. M. Bakker
}

Accepted: 2 December 2010/Published online: 30 April 2011

(C) The Author(s) 2011. This article is published with open access at Springerlink.com

\begin{abstract}
Despite significant advances in crop protection, plant diseases cause a $20 \%$ yield loss in food and cash crops worldwide. Therefore, interactions between plants and pathogens have been studied in great detail. In contrast, the interplay between plants and non-pathogenic microorganisms has received scant attention, and differential responses of plants to pathogenic and non-pathogenic microorganisms are as yet not well understood. Plants affect their rhizosphere microbial communities that can contain beneficial, neutral and pathogenic elements. Interactions between the different elements of these communities have been studied in relation to biological control of plant pathogens. One of the mechanisms of disease control is induced systemic resistance (ISR). Studies on biological control of plant diseases have focused on ISR the last decade, because ISR is effective against a wide range of pathogens and thus offers serious potential for practical applications in crop protection. Such applications may however affect microbial communities associated with plant roots and interfere with the functioning of the root microbiota. Here, we review the possible impact of plant defense signaling on bacterial communities in the rhizosphere. To better assess implications of shifts in the rhizosphere microflora we first review effects of root exudates on soil microbial communities. Current knowledge on inducible defense signaling in plants is discussed in the context of recognition and systemic responses to pathogenic and beneficial microorganisms. Finally, the as yet limited knowledge on effects of plant defense on rhizosphere
\end{abstract}

R. F. Doornbos • L. C. van Loon • P. A. H. M. Bakker $(\bowtie)$

Plant-Microbe Interactions, Department of Biology,

Utrecht University,

Padualaan 8,

3584 CH Utrecht, The Netherlands

e-mail: P.A.H.M.Bakker@uu.nl microbial communities is reviewed and we discuss future directions of research that will contribute to unravel the molecular interplay of plants and their beneficial microflora.

Keywords Biological control $\cdot$ Induced systemic resistance $\cdot$ Microbial diversity $\cdot$ Rhizosphere $\cdot$ Root colonization $\cdot$ Root exudates $\cdot$ Systemic acquired resistance

Contents

1. Introduction $\ldots \ldots \ldots \ldots \ldots \ldots \ldots \ldots \ldots$

2. Bacterial abundance and diversity in soil........ 2

2.1 Root exudates influence soil microbial communities . $\ldots \ldots \ldots \ldots \ldots \ldots \ldots \ldots$

2.2 Plants affect their microbial rhizosphere community. .

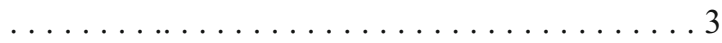

2.3 Plant-microbe interactions in the rhizosphere. . .4

3. Biological control of pathogens by beneficial bacteria . . 5

3.1 Competition for iron. . . . . . . . . . . 5

3.2 Antibiosis . . . . . . . . . . . . . . . . . . . . . . . .

3.3 Lytic enzymes. . . . . . . . . . . . . . 6

3.4 Induction of systemic resistance. . . . . . . . . . . . . .

4. Activation of plant inducible defense responses . . . 7

4.1 Inducible defense signaling. . . . . . . . . . 8

4.1.1 Systemic acquired resistance signaling . . . . 8

4.1.2 Induced systemic resistance signaling . . . . .99

5. Impact of defense on the rhizosphere microflora. . . .9

6. Concluding remarks. . . . . . . . . . 10

\section{Introduction}

Plants are under continuous attack by pathogenic microorganisms and pest insects. Despite significant advances that 
have been achieved to prevent crop losses due to diseases (Cook 2000), it is estimated that plant diseases cause a $20 \%$ yield loss in food and cash crops worldwide (Schumann and D'Arcy 2006). Disease incidence can be minimized by agricultural practices such as crop rotation, the application of chemical pesticides and breeding of resistant crop varieties. However, occurrence of pesticide-tolerant pathogens, the banning of chemical pesticides, and public concern about genetically modified crops, urge the development of biological control of plant diseases (Alabouvette et al. 2006). According to Cook and Baker (1983), "Biological control is the reduction of the amount of inoculum or diseaseproducing activity of a pathogen accomplished by or through one or more organisms other than man." There are multiple mechanisms by which naturally occurring beneficial bacteria and fungi can suppress disease incidence or severity, including antibiosis, competition for nutrients and space, and the production of lyctic enzymes (Weller 1988; Chet et al. 1990; Chet and Inbar 1994; Handelsman and Stabb 1996; Raaijmakers et al. 2002; Haas and Defago 2005; Van Loon 2007). Of special interest is the enhancement of plant innate defense responses against pathogens by beneficial bacteria and fungi that occur naturally on plant roots (Zehnder et al. 2001; Kloepper et al. 2004; Hoitink et al. 2006; Van Wees et al. 2008; Segarra et al. 2009). This induced resistance of plant defenses is effective against a wide variety of plant pathogens for prolonged periods. It is unknown, however, how the natural microflora on plant roots, that plays an important role in maintaining plant health, reacts to an augmented defensive state of the plant. Whereas fungi, oomycetes, and protozoa constitute important elements of the microbiota associated with plants, this review focuses on the more extensively studied bacterial communities in the rhizosphere.

\section{Bacterial abundance and diversity in soil}

The number of prokaryotic cells on earth is estimated to exceed $10^{30}$, of which the biggest fraction occurs in the soil (Whitman et al. 1998). The soil matrix is a favorable niche for bacteria since both temperature and humidity are relatively stable (Lavelle and Spain 2001). The community structure of the indigenous bacterial microflora in soil is determined by many variables, including geographic location and soil structure (Gelsomino et al. 1999), soil particle size (Postma and Van Veen 1990; Ranjard et al. 2000; Sessitsch et al. 2001), mineral composition (Carson et al. 2009), and agricultural practices (Benizri et al. 2007; Rooney and Clipson 2009). Fierer and Jackson (2006) analyzed almost 100 soil samples from across the North and the South American continent by DNA fingerprinting methods to compare the bacterial community composition and diversity across sites. The authors showed that the diversity of soil bacterial communities differed by edaphic variables, particularly $\mathrm{pH}$, whereas site temperature and latitude were of no influence. In general, pH-neutral soils showed a higher bacterial diversity, whereas acidic soils were least diverse.

Such extensive molecular studies were impossible until a relatively short time ago, when microbial abundance could be assessed mainly by cultivation-dependent techniques, of which counting of bacterial colony-forming units (cfu) on (semi-)selective media was the most popular. But also other methods, such as assessing bacterial enzymatic activities or measurement of soil respiration were of valuable use (Jenkinson and Ladd 1981). Implementation of molecular techniques have greatly contributed to our understanding of the microbial diversity in soil, since they do not depend on a culturable-dependent bias. For instance, PCR-fingerprinting techniques based on differences in the nucleotide sequence of phylogenetic markers, of which the small subunit $16 \mathrm{~S}$ rDNA is predominantly used, are now widely employed. Nevertheless, culturable-dependent techniques remain important for the physiological and genetic characterization of specific bacterial species containing functionally important traits. Hence, culturable plating methods are still required (Nichols 2007) and further optimized (Janssen et al. 2002).

Microbial diversity is now estimated to comprise up to $10^{7}$ species. Hence, describing bacterial community structure is still a daunting and challenging task (Hughes et al. 2001; Bent and Forney 2008; Little et al. 2008). Torsvik et al. (1990) demonstrated that the number of bacterial genomes in a deciduous forest soil exceeded the genetic diversity found by selective plating by about 200 -fold, indicating that bacteria isolated by culturable-dependent techniques are only a fraction of the total soil bacterial diversity. The acceptance that bacterial cell densities revealed by culture-dependent techniques represent only $1-10 \%$ of the total bacterial microflora present in soil is now known as 'the great plate count anomaly' (Amann et al. 1995). Therefore, prokaryotic taxonomy is nowadays based on genomic data, which allow classification of nonculturable bacteria as well (Rosselló-Mora and Amann 2001; Konstantinidis and Tiedje 2005).

\subsection{Root exudates influence soil microbial communities}

Soil organisms have to compete for nutrients and other resources that are sparsely available in soil. Because of these limiting circumstances, bacterial proliferation in soil is slow. However, microbial activity in soil is greatly influenced by plant roots (Bais et al. 2006). The main reason for this is the loss of carbon-containing metabolites from the roots into the soil matrix as a result of rhizodeposition. Rhizodeposition includes shedding of root 
cells and the exudation, secretion and leakage of, e.g., sugars, organic acids, and amino acids into the soil (Bertin et al. 2003; Bais et al. 2006). Microorganisms can use these compounds as substrates, resulting in an increased microbial biomass and activity around the roots, the so-called rhizosphere effect. The term rhizosphere, meaning the soil compartment influenced by plant roots, was first defined in 1904 by Lorentz Hiltner (Hiltner 1904; Hartmann et al. 2008), and after a century of rhizosphere research it can be concluded that many microbial interactions occur in this specific environmental niche (Whipps 2001; Lugtenberg et al. 2002).

Up to $40 \%$ of photosynthetically fixed carbon is secreted into the rhizosphere (Bais et al. 2006). Root exudation has long been regarded as a passive process. However, increasing evidence is available that ATP-binding cassette transporters in the roots are involved in the translocation of phytochemicals into the rhizosphere, indicating that plants actively secrete metabolites into the environment (LoyolaVargas et al. 2007; Badri et al. 2008). A wide variety of plants possess specialized root cells that contain many mitochondria, Golgi stacks and Golgi-derived vesicles, indicative of active secretion of metabolites (Brigham et al. 1995, 1999; Hawes et al. 2000; Vicré et al. 2005). These cells were designated border cells; they become detached from the root and enmeshed in the mucilage surrounding the root surface (Hawes et al. 1998). Although they are common in most plant species, border cells were initially not observed in various Brassicaceae, including Arabidopsis thaliana (Driouich et al. 2007). However, Vicré et al. (2005) observed a different organization of border cells in Arabidopsis, which are therefore designated as border-like cells. Proposed functions of border cells include attraction of beneficial microorganisms, reduction of sensitivity to heavy metals such as aluminum and entrapment of pathogenic bacteria and nematodes in the mucilage surrounding the roots (Hawes 1990; Hawes et al. 2000; Miyasaka and Hawes 2001).

Among the most prevalent rhizosphere bacteria are the Pseudomonas spp., which areubiquitously present in soils, easily culturable in vitro, and possess a variety of traits that are relevant for the biological control of plant diseases. Traits of Pseudomonas spp. that enable successful rhizosphere colonization are well documented (Weller 1988; Lugtenberg et al. 2001). Among these traits is the flagellar motility towards substrates, such as the organic acids and amino acids secreted by plant roots (De Weert et al. 2002).

The composition of root exudates depends on plant species and cultivar, developmental stage, plant growth substrate, and stress factors (Uren 2000). Analysis of tomato, cucumber and sweet pepper root exudates from plants grown under gnotobiotic conditions on rock wool showed that the exudates contained higher total amounts of organic acids than of sugars. Citric, succinic, and malic acid were the major organic acids, and fructose and glucose the major sugars (Kamilova et al. 2006b). Root exudate composition is also influenced by the rhizosphere microflora itself. Application of the bacterial biocontrol strain Pseudomonas fluorescens WCS365 (WCS365) on tomato roots resulted in increased levels of total organic acids, whereas the amount of succinic acid decreased (Kamilova et al. 2006a). Inoculation of the tomato roots with the pathogenic fungus Fusarium oxysporum f. sp. radicis-lycopersici caused severe foot and root rot and led to decreased amounts of citric acid, while the amount of succinic acid increased compared with non-treated control plants (Kamilova et al. 2006a). When both WCS365 and the pathogen were present, disease was much less severe and the content of succinic acid in the root exudate was decreased (Kamilova et al. 2006a). Thus, availability and composition of the nutritional diet for microorganisms in the rhizosphere are highly dynamic. As root exudation also depends on as yet unpredictable interactions between microorganisms, the analysis of root exudates in gnotobiotic systems is just at the beginning of understanding conditions in the rhizosphere.

\subsection{Plants affect their microbial rhizosphere community}

Soil is the main reservoir of the potential bacterial rhizosphere community (Normander and Prosser 2000; De Ridder-Duine et al. 2005; Berg and Smalla 2009). Evidence is increasing that plants actively select specific elements of their bacterial rhizosphere microflora, establishing a habitat which is favorable for the plant (Latour et al. 1996; Bais et al. 2004; Garbeva et al. 2004a; Robin et al. 2007; Broeckling et al. 2008; Houlden et al. 2008; Rudrappa et al. 2008). Indeed, plant species-specific rhizosphere communities have been reported. Smalla et al. (2001) monitored the bacterial rhizosphere communities of strawberry, oilseed rape and potato for two consecutive years by the culturableindependent fingerprinting method, denaturing gradient-gel electrophoresis (DGGE). Plant species-specific rhizosphere communities were observed, and differences became more pronounced in the second year. In both years, seasonal effects on both the abundance and composition of the bacterial rhizosphere populations were also observed. Lemanceau et al. (1995) studied the effect of flax and tomato roots on the diversity of Pseudomonas populations. In their study, both plant species affected Pseudomonas populations differentially, and rhizosphere populations differed from those in bulk soil. Glandorf et al. (1993) studied the Pseudomonas diversity on the roots of potato, grass and wheat. Most characterized isolates from each crop were not observed on the other two crops, indicating that composition of Pseudomonas populations differed between these plant species. Plant genotype also affects fungal 
communities in the rhizosphere, as for example demonstrated by Viebahn et al. (2005) for ascomycete communities in the rhizospheres of field-grown potato and wheat

Plant defenses have the potential to affect bacterial populations in the rhizosphere by either recruiting beneficial bacteria or actively repressing pathogen proliferation. One of the best-studied examples is the biological control of the fungus Gaeumannomyces graminis var. tritici (Ggt), the causal agent of take-all in wheat. When wheat is continuously grown in the same field, a build-up of the pathogen occurs. However, after several years of wheat monoculture and a severe outbreak of the disease, a decrease in take-all is observed, a phenomenon known as take-all decline (TAD). TAD is associated with the proliferation of specific strains of fluorescent Pseudomonas spp. in the wheat rhizosphere that produce the antibiotic 2,4-diacetylphloroglucinol (DAPG) and successfully suppress Ggt (Weller et al. 2002; Kwak et al. 2009).

Recently, Rudrappa et al. (2008) demonstrated in a gnotobiotic system that infection of Arabidopsis with the bacterial leaf pathogen Pseudomonas syringae pv. tomato DC3000 (Pst) results in the recruitment of the biocontrol strain Bacillus subtilis FB17 to the roots. The authors demonstrated that roots of Pst-infected plants secrete large amounts of malic acid, which is a chemo-attractant for FB17, and it was postulated that diseased plants "signal for help" in the rhizosphere (Rudrappa et al. 2008).

Root exudates can also have direct defensive qualities. Pathogen-activated plant defenses can result in root secretion of antimicrobial compounds. Hairy root cultures of Ocimum basilicum challenged with Pythium ultimum produce rosmarinic acid, a caffeic acid derivative with antimicrobial activity against multiple soilborne microorganisms (Bais et al. 2002). In another study (Bais et al. 2005), it was shown that root-derived antimicrobial metabolites from Arabidopsis confer resistance to a variety of $P$. syringae pathovars. It was also predicted that transgenic plants that produce antimicrobial proteins can influence rhizosphere microbial communities (Glandorf et al. 1997)

All these results were obtained predominantly in vitro and cannot be easily extrapolated to in situ conditions. Moreover, to what extent the indigenous non-pathogenic bacterial community that is intimately associated with plants is affected by plant defenses remains mostly untouched.

\subsection{Plant-microbe interactions in the rhizosphere}

In view of the immense diversity of microbial life in the soil and the rhizosphere, it is not only important to assess microbial abundance and diversity, but also to relate the presence of the variety of microorganisms to ecological function (Kent and Triplett 2002; Torsvik and Øvreås 2002). In the natural environment, microbial root colonization leads to multiple types of physical and chemical interactions between microorganisms and plants. These interactions can vary from neutral to beneficial on the one side, and deleterious on the other side when plantpathogenic microorganisms are involved (Lugtenberg et al. 2002; Singh et al. 2004; Mercado-Blanco and Bakker 2007; Raaijmakers et al. 2009). To complicate matters, microorganisms can transition between pathogenic and symbiotic states depending on environmental conditions (Newton et al. 2010a, b)

Many non-pathogenic soil bacteria have the ability to promote the growth of plants and, therefore, are often designated as plant growth-promoting rhizobacteria (PGPR) (Kloepper et al. 1980; Glick 1995; Bloemberg and Lugtenberg 2001; Persello-Cartieaux et al. 2003; Van Loon 2007). Different mechanisms are involved, of which fixation of atmospheric nitrogen to ammonia by diazotrophs has been studied most (Dobbelaere et al. 2003). Rhizobia show a highly specific symbiotic association with leguminous plants in which the rhizobia induce the plant to form root nodules, a specialized organ wherein the rhizobia reside and provide the plant with directly available nitrogen in the form of ammonia (Oldroyd and Downie 2008). Besides fixing nitrogen, the diazotroph Azospirillum secretes several plant hormones involved in the direct promotion of plant growth, namely auxins, cytokinins and gibberellins. Auxins, which are quantitatively the most abundantly secreted hormone by Azospirillum, stimulate root development, thereby promoting growth of the whole plant (Steenhoudt and Vanderleyden 2000).

Another mechanism of plant growth stimulation by PGPR is the production of 1-aminocyclopropane-1-carboxylate (ACC) deaminase (Glick et al. 2007). ACC is the immediate precursor of the plant hormone ethylene (ET), which is involved in stress signaling and negatively regulates root elongation. The bacterial enzyme ACC deaminase hydrolyzes ACC to ammonia and $\alpha$ ketobutyrate. Glick et al. (1998) postulate that plants release ACC into the rhizosphere, and that this ACC is hydrolyzed by the bacterial ACC deaminase, thereby reducing ET-mediated suppression of root growth. This interaction is also beneficial for the bacteria, as ammonia and $\alpha$-ketobutyrate are sources of $\mathrm{N}$ and $\mathrm{C}$, respectively. Ryu et al. (2003) demonstrated that the volatiles 2,3butanediol and acetoin produced by two Bacillus spp. can also enhance growth of Arabidopsis, indicating that a physical interaction between the PGPR and the plant is not necessarily required (Ping and Boland 2004).

Besides promoting plant growth directly, plant growth promotion by PGPR can also be indirect. The rhizosphere microflora can benefit plants by increasing tolerance to abiotic stresses such as drought (2009), nutrient deficiency (Yang et 
al. 2009), and heavy metal toxicity (Zhuang et al. 2007), as well as protection against pathogens through microbial antagonism and increasing plant defensive capacity (Bent 2006; Van Loon 2007). Thus, beneficial soil bacteria can protect plants against diseases caused by different types of pathogens. A growing understanding of the mechanisms involved has made it clear that many PGPR strains have the potential to be implemented as biological control agents against plant pathogens.

\section{Biological control of pathogens by beneficial bacteria}

Soil suppressiveness is the phenomenon that in spite of the presence of a virulent pathogen and a susceptible host plant, disease does not occur. General soil suppressiveness is the capacity of the total microbial biomass to suppress the growth or activity of deleterious organisms, whereas specific soil suppressiveness generally depends on a single organism with the ability to antagonize a specific pathogenic species or genus (Weller et al. 2002). This knowledge has been implemented by introducing antagonistic bacteria to plants roots to control diseases (Weller 2007). Under commercial conditions application of fluorescent Pseudomonas spp. has been demonstrated to be very effective in suppression of soil borne diseases, for example control of Fusarium wilt in radish (Fig. 1, Leeman et al. 1995a). Microbial populations can be stimulated by the addition of organic amendments such as manure or compost (Hoitink and Boehm 1999). This can make a conducive soil suppressive (Weller et al. 2002; Garbeva et al. 2004a).

Specific suppression of plant pathogens has been found for representatives of a wide variety of bacterial genera, including Agrobacterium, Alcaligenes, Arthrobacter, Bacillus, Enter- obacter, Erwinia, Pseudomonas, Rhizobium, Serratia, Streptomyces, and Xanthomonas (Weller 1988; Whipps 2001), but also for fungi, for example non-pathogenic $F$. oxysporum (Alabouvette et al. 1998). Efficient root colonization and establishment of biocontrol bacteria is of key importance for effective suppression of deleterious organisms (Weller 1988; Lugtenberg et al. 2001). Therefore, focus has been mainly on fluorescent Pseudomonas spp. because of their excellent rootcolonizing capacity and ability to produce antimicrobial compounds (Lugtenberg et al. 2001; Haas and Keel 2003; Haas and Defago 2005; Weller 2007). Several studies have demonstrated a correlation between inoculum density and efficacy of disease suppression. For example, Raaijmakers et al. (1995) demonstrated that effective biological control of Fusarium wilt in radish by $P$. fluorescens WCS374r (WCS374r) or Pseudomonas putida WCS358r (WCS358r) required at least $10^{5} \mathrm{cfu} / \mathrm{g}$ root. A small decline in population density below this threshold resulted in a rapid decrease of efficacy. Once biocontrol bacteria are established in the rhizosphere, a wide variety of mechanisms can result in suppression of plant pathogens.

\subsection{Competition for iron}

Can suppress various soilborne diseases, for example Fusarium wilt in carnation (Duijff et al. 1994) and radish (Raaijmakers et al. 1995; De Boer et al. 2003). Because of its extremely low solubility, iron is often a limiting element in the soil and rhizosphere. Hence, most microorganisms secrete siderophores that chelate iron which is subsequently acquired through membrane receptors (Loper and Buyer 1991; Neilands 1995). Under iron-limiting conditions, WCS358 secretes the fluorescent siderophore pseudobactin358. Iron chelated by pseudobactin-358 is taken up by a

Fig. 1 Control of Fusarium wilt of radish by a seed-coating treatment with Pseudomonas fluorescens WCS347 in a commercial greenhouse that was naturally infested with Fusarium oxysporum f. sp. raphani. Plants on the right hand side were grown from seed not treated $(C)$ or treated with just a coating (MC), and plants on the left from seeds coated with the pseudomonas bacteria. (Leeman et al. 1995a). The inserted picture shows details of symptoms of Fusarium wilt of radish (left, healthy; right, completely wilted and dead)

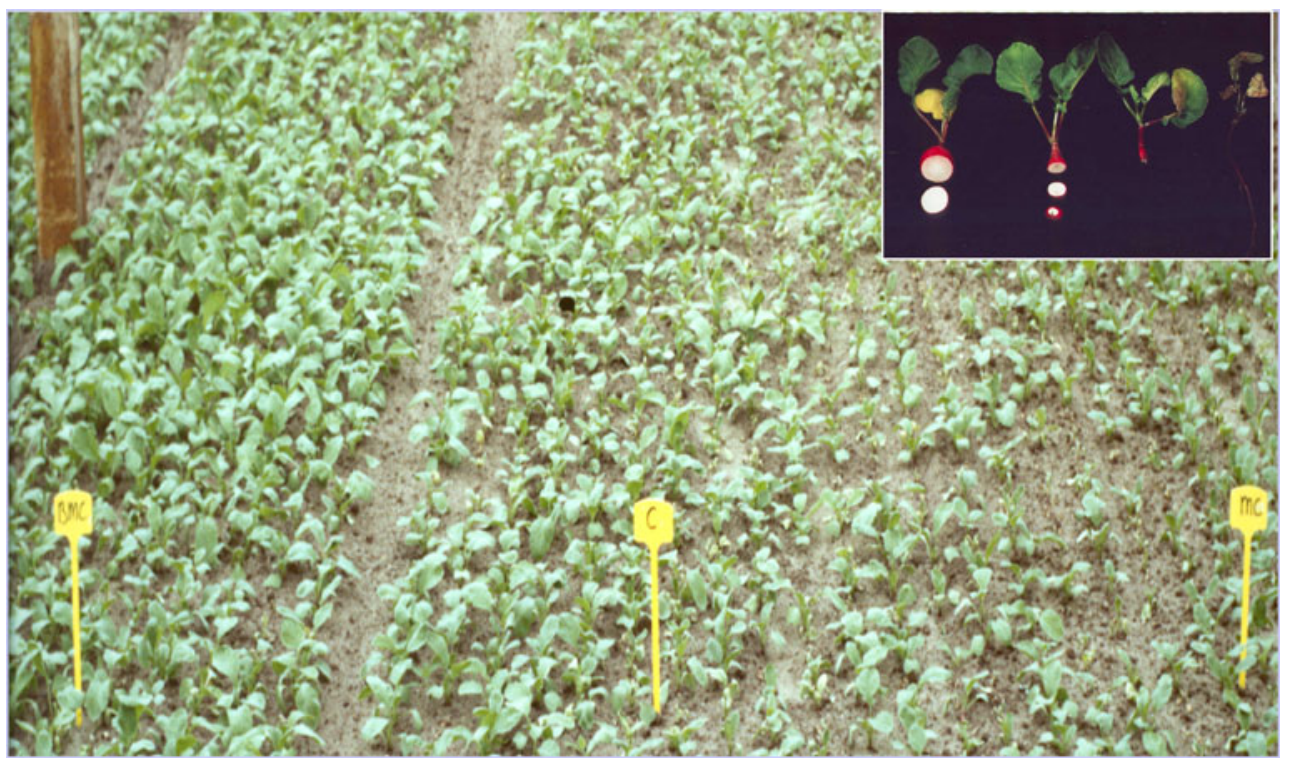


highly specific receptor, and therefore unavailable to organisms that do not possess this receptor (De Weger et al. 1988). Thus, WCS358r can monopolize the available iron in the environment, thereby effectively antagonizing deleterious organisms in their growth or activity. However, in field soils disease suppression by competition for iron is often inconsistent, since iron availability varies in time and space and can be affected by the utilization of heterologous siderophores by other organisms or degradation of the siderophore-iron complex (Loper and Henkels 1997, 1999).

Van Wuytswinkel et al. (1999) overexpressed the ironstorage protein ferritin in tobacco. As a consequence, the transgenic tobacco accumulated iron, thereby depleting the already low level of available iron in the soil. Robin et al. (2006) demonstrated that the composition of Pseudomonas spp. on ferritin-overexpressing tobacco roots was altered compared with wild-type tobacco. The Pseudomonas community on the roots of the transgenic tobacco was less susceptible to the iron-stress conditions, and moreover, individual isolates from the transgenic tobacco roots showed an increased in vitro antagonism against the plant pathogen Pythium aphanidermatum Op4 (Robin et al. 2007).

\subsection{Antibiosis}

Is the antagonistic effect of a beneficial microorganism by the production of secondary metabolites, such as antibiotics or biosurfactants. Antibiotics are low-molecular weight compounds produced by microorganisms that are deleterious to the metabolism or growth of other microorganisms. A wide variety of antibiotics exists, for example phenazines, DAPG, pyoluteorin, and pyrrolnitrin, and their involvement in biological control of plant diseases has been well studied (Raaijmakers et al. 2002; Chin-A-Woeng et al. 2003; Haas and Keel 2003; Haas and Defago 2005). Production of antibiotics is now often implicated as an important mechanism of biological control, resulting from the fact that it is a relatively easy mechanism to study and can provide a highly effective mode of action (Handelsman and Stabb 1996).

Biosurfactants are amphiphilic compounds that can damage cellular membranes, thereby causing leakage and cytolysis (Maier 2003; Raaijmakers et al. 2006). They can have antimicrobial activity against a variety of organisms, including the pathogenic oomycetes Pythium and Phytophthora, the fungus Rhizoctonia, as well as a number of Grampositive and Gram-negative bacteria that are pathogenic to humans, such as Staphylococcus aureus and Proteus vulgaris (Raaijmakers et al. 2006; Das et al. 2008).

\subsection{Lytic enzymes}

Can degrade several components that are present in the cell walls of fungi and oomycetes (Chet and Inbar 1994). A wide variety of bacterial lytic enzymes are known, including cellulases, glucanases, proteases, and chitinases. A B-1,3glucanase-producing Pseudomonas cepacia significantly decreased the incidence of diseases caused by Rhizoctonia solani, Sclerotium rolfsii, and P. ultimum (Fridlender et al. 1993). Garbeva et al. (2004b) studied the effect of agricultural practices on the composition of Pseudomonas spp. and their antagonistic activity towards $R$. solani. They observed that disease suppressiveness against $R$. solani was higher in grassland than in arable land, and linked this to an increased number of antagonistic Pseudomonas spp. possessing chitinolytic activity. However, De Boer et al. (1998) demonstrated that besides the production of lytic enzymes also other mechanisms, such as the production of antibiotics, are involved in the suppression of pathogens.

\subsection{Induction of systemic resistance}

By beneficial rhizosphere bacteria increases the defensive capacity of the plant and thereby reduces disease incidence or severity after pathogen attack (Van Loon et al. 1998). Van Peer et al. (1991), and Wei et al. (1991) independently demonstrated that induced systemic resistance (ISR) was expressed while the bacterial inoculum and the pathogen were applied and remained spatially separated. The spatial separation excluded the possibility of a direct antagonistic effect of the biocontrol bacteria on the pathogen. Unlike direct bacterial antagonism towards soilborne pathogens, ISR is also effective in above-ground plant parts against a broad range of bacterial, fungal, and oomycetous pathogens, and even sometimes against viruses, nematodes, and herbivorous insects (Van Loon et al. 1998; Van Loon and Bakker 2003; Van Oosten et al. 2008).

ISR can be induced by many different rhizosphere bacteria (Bent 2006) in a variety of plant species (Bakker et al. 2003, 2007). However, successful elicitation is based on a specific interaction between the inducing strain and the host plant (Pieterse et al. 2002; Meziane et al. 2005; Van Loon 2007; Van Wees et al. 2008). For example, Leeman et al. (1995b; 1996) demonstrated that ISR can be elicited in radish by $P$. fluorescens WCS417r (WCS417r) and WCS374r, but not by WCS358r. Conversely, WCS358r and WCS417r are capable of inducing ISR in Arabidopsis accession Columbia (Col-0), whereas WCS374r does not (Van Wees et al. 1997). However, when grown at high temperature prior to inoculation (Ran et al. 2005), or when applied at a low inoculum density (Djavaheri 2007), WCS374r does elicit ISR. Variation in the ability to express ISR is observed between different Arabidopsis accessions. Whereas the accessions Col-0 and Landsberg erecta (Ler-0) are able to express WCS417r-elicited ISR, the accessions RLD1 and Wassilewskija (WS-0) are not (Van Wees et al. 1997; Ton et al. 1999; Ton et al. 2001). Genetic studies 
revealed that the inability of RLD1 and WS-0 to express ISR is mediated by one single dominant gene, ISRI, that is associated with sensitivity of the plant to ET (Ton et al. 1999; Ton et al. 2001).

\section{Activation of plant inducible defense responses}

Plants possess different strategies to recognize and counteract pathogen attack (Jones and Dangl 2006; Boller and He 2009). As a first line of defense, the plant cell surface contains pattern recognition receptors (PRRs) that recognize potential pathogens by conserved pathogen-associated molecular patterns (PAMPs), such as flagella, outer membrane lipopolysaccharides (LPS) and other cell wall or secreted components (Zipfel 2008). Non-pathogenic microorganisms are recognized in a similar way. Hence, their elicitors are designated as microbe-associated molecular patterns (MAMPs) (Bittel and Robatzek 2007). In addition to flagella (Gómez-Gómez and Boller 2002; Zipfel et al. 2004), and LPS (Newman et al. 2007), there are various bacterial compounds that can be recognized by the plant, including $N$-acyl-L-homoserine lactones (Schuhegger et al. 2006), biosurfactants (Ongena et al. 2007; Tran et al. 2007), siderophores (Höfte and Bakker 2007), and the antibiotics DAPG (Iavicoli et al. 2003) and pyocyanin (Audenaert et al. 2002).

Recognition of any of these PAMPs/MAMPs can lead to the activation of a defense signaling cascade, thereby enhancing plant immunity (Bittel and Robatzek 2007; Van Wees et al. 2008). One of the best understood PAMP/MAMP - receptor interactions is the recognition of flagellin, the main component of the bacterial flagellum, by the PRR FLAGELLIN SENSING 2 (FLS2) (Gómez-Gómez and Boller 2000; Zipfel 2008). In Arabidopsis, Chinchilla et al. (2006) demonstrated direct binding of flg22, a conserved 22-amino-acid peptide of bacterial flagellin, to the transmembrane leucine-rich-repeatreceptor kinase FLS2. Upon binding of flg22 by FLS2, a mitogen-activated protein kinase (MAPK) signaling cascade is triggered (Asai et al. 2002). Both MAPK3 and MAPK6 are rapidly activated, resulting in the induction of plant defenses and the biosynthesis of antimicrobial metabolites (Nühse et al. 2000; Denoux et al. 2008). The bacterial Tu elongation factor (EF-Tu), and the elf18 peptide derived from the EF-Tu N terminus, seem to be recognized by Arabidopsis in a similar manner by a LRR receptor kinase called EFR (Zipfel et al. 2006). Early signaling in recognition of flg 22 and EF-Tu by FLS2 and EFR involves calcium-associated membrane anion channel opening (Jeworutzki et al. 2010).

Although non-pathogenic microorganisms lack virulence factors and thereby the ability to effectively exploit plants, recognition of MAMPs can also lead to the elicitation of ISR (Zipfel et al. 2004; Bittel and Robatzek 2007; Van
Wees et al. 2008). Plant defenses are regulated by a complex network of signaling pathways (Koornneef and Pieterse 2008; Grant and Jones 2009), in which the plant hormones salicylic acid (SA), jasmonic acid (JA), and ET play major roles (Thomma et al. 2001; Pozo et al. 2004; Van Loon et al. 2006; Loake and Grant 2007). Also other hormones, such as abscisic acid, auxins, gibberellins, cytokinins and brassinosteroids are involved (Grant and Jones 2009; Pieterse et al. 2009). By using hormone signaling mutants, Pieterse et al. $(1996,1998)$ demonstrated that the signaling pathway underlying ISR in Arabidopsis differs from the classic form of systemically induced resistance, systemic acquired resistance (SAR), that results from limited pathogen infection (Ross 1961). Whereas SAR is associated with local and systemic accumulation of SA and the expression of pathogenesis-related (PR) genes (Métraux et al. 1990; Uknes et al. 1992; Sticher et al. 1997; Mauch-Mani and Métraux 1998; Durrant and Dong 2004), ISR requires responsiveness of the plant to JA and ET (Pieterse et al. 1996, 1998). However, ISR is not associated with an increased synthesis of these hormones, nor with an increased expression of known defense-related genes (Van Wees et al. 1999; Pieterse et al. 2000; Verhagen et al. 2004).

Both SAR and ISR enhance plant innate immunity by a mechanism designated priming, which enables the plant to react faster and more strongly to subsequent pathogen attack (Conrath et al. 2002, 2006). Primed plants do not exhibit augmented expression of defense-related genes in the absence of pathogen attack. Instead, an accelerated activation of plant defenses occurs upon pathogen recognition, providing a stronger and faster defense response. Possible mechanisms of priming in SAR and ISR involve the expression of signaling components such as transcription factors (Van der Ent et al. 2008, 2009), or the activation of protein kinases such as MAPK3 and MAPK6 (Beckers et al. 2009), which stay inactive until pathogen recognition. Another mechanism behind priming appears to be a change in chromatin structure (Bruce et al. 2007; Van den Burg and Takken 2009). DNA methylation and/or histone modification can result in a more accessible chromatin structure, allowing a quicker transcriptional response upon pathogen attack.

Expression of plant defenses is necessary for a plant to ward off attack by a pathogen. However, the expression of plant defenses in the absence of deleterious organisms involves fitness costs (Heil 2002; Heil and Baldwin 2002; Heidel et al. 2004; Van Hulten et al. 2006; Walters and Heil 2007). The Arabidopsis mutant cprl (constitutive expressor of PR genes 1) constitutively expresses SA-dependent defenses and is more resistant to a variety of pathogens (Bowling et al. 1994). However, cprl has a dwarf phenotype and produces fewer seeds compared with the 
wild-type Col-0 plants (Bowling et al. 1994; Heidel et al. 2004). In contrast, the edrl (enhanced disease resistance 1) mutation in Arabidopsis results in a plant that is constitutively primed for SA-dependent defenses (Frye and Innes 1998). The edr1 mutant shows only a slightly lower fitness compared with the wild type and performed considerably better than cprl in the absence of pathogens (Van Hulten et al. 2006). Moreover, upon challenge inoculation with Pst or Hyaloperonospora arabidopsidis, edrl displayed a comparable level of disease protection as $c p r l$, similar to that in wild-type plants in which defenses were activated by chemical elicitors. These observations indicate that priming of inducible defenses outweighs the fitness costs in an environment in which disease occurs (Van Hulten et al. 2006).

\subsection{Inducible defense signaling}

In general, pathogens with a necrotrophic lifestyle are resisted by JA/ET-dependent defenses, whereas SAdependent defenses are effective against pathogens with a biotrophic lifestyle (Glazebrook 2005). This differential effectiveness of plant defenses is also displayed by ISR and SAR (Ton et al. 2002). For example, ISR is effective against the necrotrophic fungus Alternaria brassicicola whereas SAR is not, while SAR is effective against the biotrophic turnip crinkle virus, and ISR is not. A schematic representation of the SAR and ISR signal-transduction pathways is shown in Fig. 2.

\subsubsection{Systemic acquired resistance signaling}

By transforming tobacco with the bacterial gene $N a h G$, which encodes the enzyme salicylate hydroxylase that converts SA into catechol, it was demonstrated that accumulation of SA is required for the expression of PR proteins and SAR (Gaffney et al. 1993; Delaney et al. 1994; Van Loon 1997). Similarly, Arabidopsis genotypes that are unable to synthesize SA, such as the mutants sid1 (salicylic acid induction-deficient 1), sid2, and pad4 (phytoalexin deficient 4), are deficient in the expression of both PR proteins and SAR as well (Lawton et al. 1995; Zhou et al. 1998; Nawrath and Métraux 1999). Local synthesis of SA is necessary for the activation of SAR. However, SA is not the mobile signal required for the systemic activation of SAR (Vernooij et al. 1994). In a search for this mobile signal, it was proposed that locally produced SA is esterified to methyl salicylate (MeSA), which is transported to systemic tissues and there converted back to SA (Seskar et al. 1998; Park et al. 2007). However, Attaran et al. (2009) demonstrated that in Arabidopsis the synthesis of MeSA does not coincide with the expression of SAR. Earlier, Maldonado et al. (2002) suggested that a lipid-
Rhizobacteria

LPS Flagellin Other MAMPs

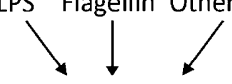

plant receptors

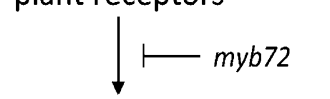

JA response $\longmapsto$ jar1

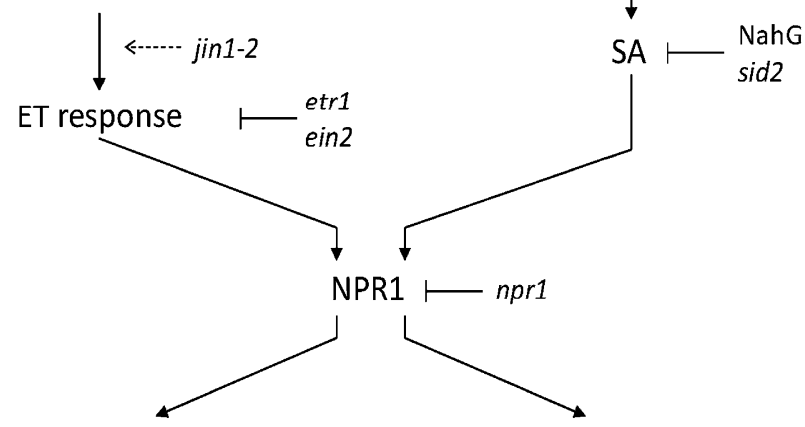

Defensive compounds

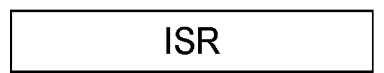

PRs; defensive compounds

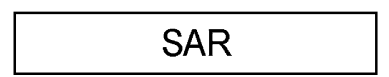

Fig. 2 Schematic representation of the signal-transduction pathways leading to rhizobacteria-mediated induced systemic resistance (ISR) and pathogen-induced systemic acquired resistance $(S A R)$ in Arabidopsis. Solid arrows indicate stimulation; dotted arrows indicate priming for stimulation, T-bars indicate repression (see text for details). PAMPS pathogen-associated molecular patterns, LPS lipopolysaccharides, MAMPS microbe-associated molecular patterns, $J A$ jasmonic acid, ET ethylene, $S A$ salicylic acid, $P R S$ pathogenesisrelated proteins. Adapted from Pieterse et al. (1998) and Ton et al. (2006)

based molecule could function as the long-distance regulator of SAR in Arabidopsis. The mutant dirl (defective in induced resistance 1) is impaired in the synthesis of a lipidtransfer protein and in the systemic, but not the local, accumulation of SA. Moreover, a recent study by Jung et al. (2009) suggests azelaic acid to be the transported mobile signal required for the systemic activation of SAR in Arabidopsis. Although also JA signaling occurs in the early response of SAR, JA biosynthesis, or downstream signaling are not required for the systemic expression of SAR (Truman et al. 2007; Vlot et al. 2008; Attaran et al. 2009).

Subsequent signaling in the SAR signal-transduction pathway requires the function of NON-EXPRESSOR OF $P R$ GENES 1 (NPR1), also known as NON-INDUCIBLE IMMUNITY 1, or SALICYLIC ACID-INSENSITIVE 1, which serves as a key regulator of induced resistance signaling (Cao et al. 1994; Pieterse and Van Loon 2004). Upon SA accumulation, inactive NPR1 oligomers in the cytosol are reduced to active monomers, and translocated into the nucleus (Kinkema et al. 2000; Mou et al. 2003). There, NPR1 interacts with TGA and WRKY transcription factors to regulate the expression of defense-related genes, 
such as PR-1 (Zhang et al. 1999; Pieterse and Van Loon 2004; Wang et al. 2006). Besides this regulatory function, NPR1 also controls the expression of the protein secretory machinery, which is required for the translocation of defense proteins into the apoplast (Wang et al. 2005).

\subsubsection{Induced systemic resistance signaling}

By using a transcriptomic approach, Verhagen et al. (2004) found only priming of defense-related genes in the leaves. However, WCS417r-treated roots showed upregulation of 97 genes. Among these, the R2R3-MYB-like transcription factor gene $M Y B 72$ was specifically expressed in the roots upon colonization by $P$. putida WCS358r, P. fluorescens WCS417r, and crude cell walls of WCS417r, concomitant with the elicitation of ISR (Verhagen et al. 2004; Van der Ent et al. 2008). MYB72 binds in vitro to the ETHYLENE INSENSITIVE3 (EIN3)-LIKE transcription factor, indicating a link with the ET-response pathway. Moreover, MYB72 was found to be essential for the activation of ISR, since $m y b 72$ knockout mutants did not exhibit ISR after treatment with WCS417r. However, activation of MYB72 is not sufficient for the expression of ISR, since overexpressing 35S::MYB72 Arabidopsis plants did not show enhanced resistance against different pathogens tested (Van der Ent et al. 2008).

Microarray analysis further demonstrated that the promoter regions of MeJA-responsive genes that were primed by WCS417r were enriched for binding sites of the transcription factor MYC2 (Pozo et al. 2008). Moreover, $M Y C 2$ expression was found to be upregulated in the leaves of WCS417r-induced plants. A role for MYC2 in the ISR signal-transduction pathway was demonstrated by the observation that the MYC2 mutant, jasmonate-insensitive 1, had lost the ability to express WCS417r-elicited ISR.

\section{Impact of defense on the rhizosphere microflora}

Plant defenses are directed against pathogenic microorganisms, but possible effects on the indigenous rhizosphere microflora have hardly been investigated. Generating such knowledge will allow more sensible implementation of beneficial rhizosphere bacteria for biological control of diseases. Whereas interactions between plants and pathogens have been studied in great detail, the interplay between plants and non-pathogenic microorganisms has received scant attention (Bisseling et al. 2009). Most investigations in which a possible impact of plant defenses has been studied use Arabidopsis as model plant, because a wide variety of wild-type plants, constitutive expressors, as well as mutants impaired in the expression of defenses are available.

It can be postulated that highly susceptible plants harbor a more diverse and/or more abundant microbial community compared with more resistant plants. The impact of constitutive expression of SAR on bacterial community structure in the rhizosphere of Arabidopsis was studied using T-RFLP (Hein et al. 2008). Although differences in bacterial diversity were observed, they could not be linked to the expression of induced resistance. Bacterial communities in the rhizosphere of Arabidopsis accessions RLD and WS- 0 were distinct from those of Col- 0 and five other accessions (Micallef et al. 2009). These data do suggest a relation between defense signaling and bacterial community structure, because compared with the other accessions, RLD and WS-0 are relative insensitive to ET and impaired in the expression of ISR (Ton et al. 1999; Ton et al. 2001). In tobacco, ET insensitivity also affects the indigenous microflora, as evidenced by studies that used ET-insensitive transgenic plants. Knoester et al. (1998) and Geraats et al. (2002, 2003, 2007) observed spontaneous infection by various soilborne fungi and oomycetes in ET-insensitive Tetr tobacco. Based on DGGE fingerprint analysis of amplified bacterial ribosomal DNA, it was concluded that also the indigenous rhizosphere bacterial community structure of tobacco was affected by ET insensitivity (Geraats 2003).

Because of the complexity of interactions that occur between microorganisms and plants, perturbations could be provoked in multiple ways. As stated earlier, plant root exudates can selectively attract microorganisms, resulting in the establishment of a rhizosphere microflora that is favorable to plant growth (Latour et al. 1996; Bais et al. 2004; Garbeva et al. 2004a; Robin et al. 2007; Broeckling et al. 2008; Houlden et al. 2008; Rudrappa et al. 2008). The composition of root exudates is a reflection of the plants physiological state which in turn can be affected by both biotic and abiotic factors. For example, the expression of inducible plant defenses requires energy. This energy demand is nicely demonstrated for Arabidopsis in the observation that there is a significant fitness cost for the activation of defense responses (Van Hulten et al. 2006). As indicated by local decreases of photosynthetic activity, activated plant defenses require energy in order to prioritize production of defense-related compounds (Berger et al. 2007; Bolton 2009). Increased expression of apoplastic invertases is observed under stress conditions, resulting in increased local sink strength to provide hexoses for stress alleviation (Roitsch et al. 2003; Bolton 2009). Increased transport of carbohydrates into the cells deprives apoplastcolonizing pathogens from readily available nutrients (Fotopoulos et al. 2003). In a similar way non-pathogenic microorganisms may be affected by changes in the plants energy balance.

A more direct effect on the non-pathogenic microflora can be expected from secondary metabolites with antimicrobial activity that are secreted as a results of activation of defense 
responses. Roots of Arabidopsis treated with SA secrete numerous secondary metabolites (Walker et al. 2003). These include butanoic acid, ferulic acid, and 3-indolepropanoic acid, all of which exhibit in vitro antibacterial activity against pathogenic Erwinia spp., Xanthomonas campestris, and $P$. syringae at the concentrations detected in the exudates. Whereas growth of a non-pathogenic $P$. fluorescens was less sensitive to these exudates, effects on the microbial community were not investigated in this study. Activation of SA-dependent defenses by foliar application of SA to field-grown Arabidopsis resulted in a reduced diversity of bacterial endophytes in the leaves (Kniskern et al. 2007). In a similar experiment in the greenhouse, no significant effects of activated SA-dependent defenses on the bacterial rhizosphere microflora of Arabidopsis were observed (Doornbos et al. 2009).

Activation of SA-dependent defenses in barley by application of BION, which contains benzothiadiazole, a functional analog of SA, did not affect the composition of free-living soil biota or infection by mycorrhizal fungi (Sonnemann et al. 2002). However, increased root infections by the parasitic nematode Pratylenchus were evident. One of the explanations for these results is a signaling conflict or trade-off between different types of defense responses, as suggested by Heil (2001). Activation of SAdependent defenses antagonizes the JA-dependent signaling pathway (Beckers and Spoel 2006; Koornneef and Pieterse 2008; Grant and Jones 2009). Thus, prioritizing of SAdependent defenses over JA-dependent defenses can result in an increased susceptibility to deleterious organisms that are resisted by JA-dependent defense responses.

\section{Concluding remarks}

We are just at the start of understanding the complex interactions between plant roots and its highly diverse and dynamic microflora.The ability of plants to react differentially to microbial pathogens and to beneficial microorganisms is crucial for its survival. Pathogens need to be stopped quickly and efficiently, whereas the beneficials should be stimulated. Such an ideal situation seems to exist in the study by Rudrappa et al. (2008), who demonstrated that infection of Arabidopsis leaves by P. syringae pv tomato leads to increased rhizosphere populations of ISR eliciting bacteria. The ISR eliciting, beneficial P. fluorescens and P. putida strains were reported to have reduced root colonization on a mutant of Arabidopsis affected in the expression of ISR (Doornbos et al. 2009), suggesting that there is a mutual benefit of ISR for the plant, becoming more resistant to pathogens, and the bacteria, reaching higher population densities. Whereas only a limited number of studies have investigated effects of plant defense on the non-pathogenic and beneficial microflora, most of these studies suggest that effects on the indigenous microflora are negligible. Development of methodologies to study shifts in the rhizosphere microflora have been stimulated by studies that have focused on the impact of introducing genetically modified bacteria that produce broad spectrum antibiotics (Glandorf et al. 2001; Bakker et al. 2002; Blouin-Bankhead et al. 2004; Timms-Wilson et al. 2004; Viebahn et al. 2003, 2006). Most of those studies used fingerprinting techniques of group specific PCR amplified 16S (bacteria) or $18 \mathrm{~S}$ (fungi) rDNA, enabling detection of shifts but lacking power to identify the organisms affected. The new generation PhyloChip that contains 60,000 bacterial operational taxonomic units (Hazen et al. 2010) facilitates assessment of qualitative and quantitative shifts in microbial communities. Unraveling the molecular interplay of plant-microbe interactions will not only enable us to manipulate plant defense to our benefit, but more so to stimulate development of a beneficial rhizosphere microflora.

Open Access This article is distributed under the terms of the Creative Commons Attribution Noncommercial License which permits any noncommercial use, distribution, and reproduction in any medium, provided the original author(s) and source are credited.

\section{References}

Alabouvette C, Schippers B, Lemanceau P, Bakker PAHM (1998) Biological control of fusarium wilts: towards development of commercial products. In: Boland GJ, Kuykendall LD (eds) Plantmicrobe interactions and biological control. Marcel Dekker, New York, pp 15-36

Alabouvette C, Olivain C, Steinberg C (2006) Biological control of plant diseases: the European situation. Eur J Plant Pathol 114:329-341. doi:10.1007/s10658-005-0233-0

Amann RI, Ludwig W, Schleifer KH (1995) Phylogenetic identification and in situ detection of individual microbial cells without cultivation. Microbiol Rev 59:143-169

Asai T, Tena G, Plotnikova J, Willmann MR, Chiu W-L, Gomez-Gomez L, Boller T, Ausubel FM, Sheen J (2002) MAP kinase signalling cascade in Arabidopsis innate immunity. Nature 415:977-983

Attaran E, Zeier TE, Griebel T, Zeier J (2009) Methyl salicylate production and jasmonate signaling are not essential for systemic acquired resistance in Arabidopsis. Plant Cell 21:954-971. doi:10.1105/tpc. 108.063164

Audenaert K, Pattery T, Cornelis P, Höfte M (2002) Induction of systemic resistance to Botrytis cinerea in tomato by Pseudomonas aeruginosa 7NSK2: Role of salicylic acid, pyochelin, and pyocyanin. Mol Plant-Microb Interact 15:1147-1156

Badri DV, Loyola-Vargas VM, Broeckling CD, De-la-Pena C, Jasinski M, Santelia D, Martinoia E, Sumner LW, Banta LM, Stermitz F, Vivanco JM (2008) Altered profile of secondary metabolites in the root exudates of Arabidopsis ATP-binding cassette transporter mutants. Plant Physiol 146:762-771. doi:10.1104/pp.107.109587

Bais HP, Walker TS, Schweizer HP, Vivanco JM (2002) Root specific elicitation and antimicrobial activity of rosmarinic acid in hairy root cultures of Ocimum basilicum. Plant Physiol Biochem 40:983-995 
Bais HP, Park SW, Weir TL, Callaway RM, Vivanco JM (2004) How plants communicate using the underground information superhighway. Trends Plant Sci 9:26-32. doi:10.1016/j.tplants.2003.11.008

Bais HP, Prithiviraj B, Jha AK, Ausubel FM, Vivanco JM (2005) Mediation of pathogen resistance by exudation of antimicrobials from roots. Nature 434:217-221. doi:10.1038/nature03356

Bais HP, Weir TL, Perry LG, Gilroy S, Vivanco JM (2006) The role of root exudates in rhizosphere interactions with plants and other organisms. Annu Rev Plant Biol 57:233-266. doi:10.1146/ annurev.arplant.57.032905.105159

Bakker PAHM, Glandorf DCM, Viebahn M, Ouwens TWM, Smit E, Leeflang P, Wernars K, Thomashow LS, Thomas-Oates JE, Van Loon LC (2002) Effects of Pseudomonas putida modified to produce phenazine-1-carboxylic acid and 2, 4-diacetylphloroglucinol on the microflora of field grown wheat. Antonie Leeuwenhoek 81:617624

Bakker PAHM, Ran LX, Pieterse CMJ, Van Loon LC (2003) Understanding the involvement of induced systemic resistance in rhizobacteria-mediated biocontrol of plant diseases. Can $\mathrm{J}$ Plant Pathol 25:5-9

Bakker PAHM, Pieterse CMJ, Van Loon LC (2007) Induced systemic resistance by fluorescent Pseudomonas spp. Phytopathology 97:239-243. doi:10.1094/PHYTO-97-2-0239

Beckers GJM, Spoel SH (2006) Fine-tuning plant defence signalling: salicylate versus jasmonate. Plant Biol 8:1-10. doi:10.1055/s-2005872705

Beckers GJM, Jaskiewicz M, Liu Y, Underwood WR, He SY, Zhang S, Conrath U (2009) Mitogen-activated protein kinases 3 and 6 are required for full priming of stress responses in Arabidopsis thaliana. Plant Cell 21:944-953. doi:10.1105/tpc.108.062158

Benizri E, Nguyen C, Piutti S, Slezack-Deschaumes S, Philippot L (2007) Additions of maize root mucilage to soil changed the structure of the bacterial community. Soil Biol Biochem 39:1230-1233. doi:10.1016/j.soilbio.2006.12.026

Bent E (2006) Induced systemic resistance mediated by plant growthpromoting rhizobacteria (PGPR) and fungi (PGPF). In: Tuzun S, Bent $\mathrm{E}$ (eds) Multigenic and induced systemic resistance in plants. Springer, New York, pp 225-258

Bent SJ, Forney LJ (2008) The tragedy of the uncommon: understanding limitations in the analysis of microbial diversity. ISME J 2:689-695. doi:10.1038/ismej.2008.44

Berg G, Smalla K (2009) Plant species and soil type cooperatively shape the structure and function of microbial communities in the rhizosphere. FEMS Microbiol Ecol 68:1-13. doi:10.1111/j.15746941.2009.00654.x

Berger S, Sinha AK, Roitsch T (2007) Plant physiology meets phytopathology: plant primary metabolism and plant-pathogen interactions. J Exp Bot 58:4019-4026. doi:10.1093/jxb/erm298

Bertin C, Yang X, Weston LA (2003) The role of root exudates and allelochemicals in the rhizosphere. Plant Soil 256:67-83

Bisseling T, Dangl JL, Schulze-Lefert P (2009) Next-generation communication. Science 324:691. doi:10.1126/science.1174404

Bittel P, Robatzek S (2007) Microbe-associated molecular patterns (MAMPs) probe plant immunity. Curr Opin Plant Biol 10:335341. doi:10.1016/j.pbi.2007.04.021

Bloemberg GV, Lugtenberg BJJ (2001) Molecular basis of plant growth promotion and biocontrol by rhizobacteria. Curr Opin Plant Biol 4:343-350

Blouin-Bankhead S, Landa BB, Lutton E, Weller DM, McSpaddenGardener BB (2004) Minimal changes in rhizobacterial population structure following root colonization by wild type and transgenic biocontrol strains. FEMS Microbiol Ecol 49:307-318. doi:10.1016/j.femsec.2004.04.005

Boller T, He SY (2009) Innate immunity in plants: an arms race between pattern recognition receptors in plants and effectors in microbial pathogens. Science 323:742-744. doi:10.1126/science.1171647
Bolton MD (2009) Primary metabolism and plant defense- fuel for the fire. Mol Plant-Microb Interact 22:487-497. doi:10.1094/ MPMI-22-5-0487

Bowling SA, Guo A, Cao H, Gordon AS, Klessig DF, Dong X (1994) A mutation in Arabidopsis that leads to constitutive expression of systemic acquired resistance. Plant Cell 6:1845-1857

Brigham LA, Woo H-H, Nicoll SM, Hawes MC (1995) Differential expression of proteins and mRNA from border cells and root-tips of pea. Plant Physiol 109:457-463

Brigham LA, Michaels PJ, Flores HE (1999) Cell-specific production and antimicrobial activity of naphthoquinones in roots of Lithospermum erythrorhizon. Plant Physiol 119:417-428

Broeckling CD, Broz AK, Bergelson J, Manter DK, Vivanco JM (2008) Root exudates regulate soil fungal community composition and diversity. Appl Environ Microbiol 74:738-744. doi:10.1128/AEM.02188-07

Bruce TJA, Matthes MC, Napier JA, Pickett JA (2007) Stressful "memories" of plants: evidence and possible mechanisms. Plant Sci 173:603-608. doi:10.1016/j.plantsci.2007.09.002

Cao H, Bowling SA, Gordon AS, Dong X (1994) Characterization of an Arabidopsis mutant that is nonresponsive to inducers of systemic acquired resistance. Plant Cell 6:1583-1592

Carson JK, Campbell L, Rooney D, Clipson N, Gleeson DB (2009) Minerals in soil select distinct bacterial communities in their microhabitats. FEMS Microbiol Ecol 67:381-388. doi:10.1111/ j.1574-6941.2008.00645.x

Chet I, Inbar J (1994) Biological control of fungal pathogens. Appl Biochem Biotechnol 48:37-43

Chet I, Ordentlich A, Shapira R, Oppenheim A (1990) Mecahnisms of biocontrol of soil-borne plant pathogens by rhizobacteria. Plant Soil 129:85-92

Chin-A-Woeng TFC, Bloemberg GV, Lugtenberg BJJ (2003) Phenazines and their role in biocontrol by Pseudomonas bacteria. New Phytol 157:503-523. doi:10.1046/j.1469-8137.2003.00686

Chinchilla D, Bauer Z, Regenass M, Boller T, Felix G (2006) The Arabidopsis receptor kinase FLS2 binds flg22 and determines the specificity of flagellin perception. Plant Cell 18:465-476. doi:10.1105/tpc. 105.036574

Conrath U, Pieterse CMJ, Mauch-Mani B (2002) Priming in plantpathogen interactions. Trends Plant Sci 7:210-216

Conrath U, Beckers GJM, Flors V, Garcia-Agustin P, Jakab G, Mauch F, Newman MA, Pieterse CMJ, Poinssot B, Pozo MJ, Pugin A, Schaffrath U, Ton J, Wendehenne D, Zimmerli L, Mauch-Mani B (2006) Priming: Getting ready for battle. Mol Plant-Microb Interact 19:1062-1071. doi:10.1094/MPMI-19-1062

Cook RJ (2000) Advances in plant health management in the twentieth century. Annu Rev Phytopathol 38:95-116

Cook RJ, Baker KF (1983) The nature and practice of biological control of plant pathogens. APS Press, St. Paul

Das P, Mukherjee S, Sen R (2008) Antimicrobial potential of a lipopeptide biosurfactant derived from a marine Bacillus circulans. J Appl Microbiol 104:1675-1684. doi:10.1111/j.13652672.2007.03701.x

De Boer W, Klein-Gunnewiek PJA, Lafeber P, Janse JD, Spit BE, Woldendorp JW (1998) Anti-fungal properties of chitinolytic dune soil bacteria. Soil Biol Biochem 30:193-203

De Boer M, Born P, Kindt F, Keurentjes JJB, Van der Sluis I, Van Loon LC, Bakker PAHM (2003) Control of Fusarium wilt of radish by combining Pseudomonas putida strains that have different disease-suppressive mechanisms. Phytopathology 93:626-632. doi:10.1094/PHYTO.2003.93.5.626

De Ridder-Duine AS, Kowalchuk GA, Klein Gunnewiek PJA, Smant W, Van Veen JA, De Boer W (2005) Rhizosphere bacterial community composition in natural stands of Carex arenaria (sand sedge) is determined by bulk soil community composition. Soil Biol Biochem 37:349-357. doi:10.1016/j.soilbio.2004.08.005 
De Weert S, Vermeiren H, Mulders IHM, Kuiper I, Hendrickx N, Bloemberg GV, Vanderleyden J, De Mot R, Lugtenberg BJJ (2002) Flagella-driven chemotaxis towards exudate components is an important trait for tomato root colonization by Pseudomonas fluorescens. Mol Plant-Microb Interact 15:1173-1180. doi:10.1094/MPMI.2002.15.11.1173

De Weger LA, Van Arendonk JJCM, Recourt K, Van der Hofstad GAJM, Weisbeek PJ, Lugtenberg B (1988) Siderophoremediated uptake Of $\mathrm{Fe}-3+$ by the plant growth-stimulating Pseudomonas putida strain WCS358 and by other rhizosphere microorganisms. J Bacteriol 170:4693-4698

Delaney TP, Uknes S, Vernooij B, Friedrich L, Weymann K, Negrotto D, Gaffney T, Gut-Rella M, Kessmann H, Ward E, Ryals J (1994) A central role of salicylic acid in plant disease resistance. Science 266:1247-1250

Denoux C, Galletti R, Mammarella N, Gopalan S, Werck D, De Lorenzo G, Ferrari S, Ausubel FM, Dewdney J (2008) Activation of defense response pathways by OGs and Flg22 elicitors in Arabidopsis seedlings. Mol Plant 1:423-445. doi:10.1093/mp/ssn019

Djavaheri M. (2007) Iron-regulated metabolites of plant growth promoting Pseudomonas fluorescens WCS374: their role in induced systemic resistance. Ph.D. thesis, Utrecht University, the Netherlands

Dobbelaere S, Vanderleyden J, Okon Y (2003) Plant growthpromoting effects of diazotrophs in the rhizosphere. Crit Rev Plant Sci 22:107-149. doi:10.1080/713610853

Doornbos RF, Van Loon LC, Bakker PAHM (2009) Beneficial Pseudomonas spp. have altered root colonization on Arabidopsis thaliana mutants affected in the expression of induced systemic resistance. IOBC/WPRS Bull 43:307-310

Driouich A, Durand C, Vicré-Gibouin M (2007) Formation and separation of root border cells. Trends Plant Sci 12:14-19. doi:10.1016/j.tplants.2006.11.003

Duijff BJ, Bakker PAHM, Schippers B (1994) Suppression Of Fusarium wilt of carnation by Pseudomonas putida WCS358 at different levels of disease incidence and iron availability. Biocontrol Sci Technol 4:279-288

Durrant WE, Dong X (2004) Systemic acquired resistance. Annu Rev Phytopathol 42:185-209. doi:10.1146/annurev.phyto.42.040803. 140421

Fierer N, Jackson RB (2006) The diversity and biogeography of soil bacterial communities. Proc Natl Acad Sci USA 103:626-631. doi: 10.1073 pnas. 0507535103

Fotopoulos V, Gilbert MJ, Pittman JK, Marvier AC, Buchanan AJ, Sauer N, Hall JL, Williams LE (2003) The monosaccharide transporter gene, AtSTP4, and the cell-wall invertase, Atßfruct1, are induced in Arabidopsis during infection with the fungal biotroph Erysiphe cichoracearum. Plant Physiol 132:821-829. doi:10.1104/pp.103.021428

Fridlender M, Inbar J, Chet I (1993) Biological control of soilborne plant-pathogens by a $\beta-1,3$ glucanase-producing Pseudomonas cepacia. Soil Biol Biochem 25:1211-1221

Frye CA, Innes RW (1998) An Arabidopsis mutant with enhanced resistance to powdery mildew. Plant Cell 10:947-956

Gaffney T, Friedrich L, Vernooij B, Negrotto D, Nye G, Uknes S, Ward E, Kessmann H, Ryals J (1993) Requirement of salicylic acid for the induction of systemic acquired resistance. Science 261:754-756

Garbeva P, Van Veen JA, Van Elsas JD (2004a) Microbial diversity in soil: selection of microbial populations by plant and soil type and implications for disease suppressiveness. Annu Rev Phytopathol 42:243-270. doi:10.1146/annurev.phyto.42.012604. 135455

Garbeva P, Van Veen JA, Van Elsas JD (2004b) Assessment of the diversity, and antagonism towards Rhizoctonia solani AG3, of Pseudomonas species in soil from different agricultural regimes.
FEMS Microbiol Ecol 47:51-64. doi:10.1016/S0168-6496(03) 00234-4

Gelsomino A, Keijzer-Wolters AC, Cacco G, Van Elsas JD (1999) Assessment of bacterial community structure in soil by polymerase chain reaction and denaturing gradient gel electrophoresis. $\mathbf{J}$ Microbiol Meth 38:1-15

Geraats B.P.J. (2003) The role of ethylene perception in plant disease resistance. Ph.D. thesis, Utrecht University, the Netherlands

Geraats BPJ, Bakker PAHM, Van Loon LC (2002) Ethylene insensitivity impairs resistance to soilborne pathogens in tobacco and Arabidopsis thaliana. Mol Plant-Microb Interact 15:10781085. doi:10.1094/MPMI.2002.15.10.1078

Geraats BPJ, Bakker PAHM, Lawrence CB, Achuo EA, Höfte M, Van Loon LC (2003) Ethylene-insensitive tobacco shows differentially altered susceptibility to different pathogens. Phytopathology 93:813-821

Geraats BPJ, Bakker PAHM, Linthorst HJM, Hoekstra J, Van Loon LC (2007) The enhanced disease susceptibility phenotype of ethylene-insensitive tobacco cannot be counteracted by inducing resistance or application of bacterial antagonists. Physiol Mol Plant Pathol 70:77-87. doi:10.1016/j.pmpp.2007.07.003

Glandorf DCM, Peters LGL, Van der Sluis I, Bakker PAHM, Schippers B (1993) Crop specificity of rhizosphere pseudomonads and the involvement of root agglutinins. Soil Biol Biochem 25:981-989

Glandorf DCM, Bakker PAHM, Van Loon LC (1997) Influence of the production of antibacterial and antifungal proteins by transgenic plants on the saprophytic soil microflora. Acta Bot Neerl 46:85-104

Glandorf DCM, Verheggen P, Jansen T, Jorritsma J-W, Smit E, Leeflang P, Wernars K, Thomashow LS, Laureijs E, ThomasOates JE, Bakker PAHM, Van Loon LC (2001) Effect of genetically modified Pseudomonas putida on the fungal rhizosphere microflora of field-grown wheat. Appl Environ Microbiol 67:3371-3378. doi:10.1128/AEM.67.8.3371-3378.2001

Glazebrook J (2005) Contrasting mechanisms of defense against biotrophic and necrotrophic pathogens. Annu Rev Phytopathol 43:205-227. doi:10.1146/annurev.phyto.43.040204.135923

Glick BR (1995) The enhancement of plant growth by free-living bacteria. Can J Microbiol 41:109-117

Glick BR, Penrose DM, Li JP (1998) A model for the lowering of plant ethylene concentrations by plant growth-promoting bacteria. J Theor Biol 190:63-68

Glick BR, Todorovic B, Czarny J, Cheng Z, Duan J, McConkey B (2007) Promotion of plant growth by bacterial ACC deaminase. Crit Rev Plant Sci 26:227-242. doi:10.1080/07352680701572966

Gómez-Gómez L, Boller T (2000) FLS2: An LRR receptor-like kinase involved in the perception of the bacterial elicitor flagellin in Arabidopsis. Mol Cell 5:1003-1011

Gómez-Gómez L, Boller T (2002) Flagellin perception: a paradigm for innate immunity. Trends Plant Sci 7:251-256

Grant MR, Jones JDG (2009) Hormone (dis)harmony moulds plant health and disease. Science 324:750-752. doi:10.1126/science. 1173771

Haas D, Defago G (2005) Biological control of soil-borne pathogens by fluorescent pseudomonads. Nat Rev Microbiol 3:307-319. doi:10.1038/nrmicro1129

Haas D, Keel C (2003) Regulation of antibiotic production in rootcolonizing Pseudomonas spp. and relevance for biological control of plant disease. Annu Rev Phytopathol 41:117-153. doi:10.1146/annurev.phyto.41.052002.095656

Handelsman J, Stabb EV (1996) Biocontrol of soilborne plant pathogens. Plant Cell 8:1855-1869

Hartmann A, Rothballer M, Schmid M (2008) Lorenz Hiltner, a pioneer in rhizophere microbial ecology and soil bacteriology research. Plant Soil 312:7-14. doi:10.1007/s11104-007-9514-z

Hawes MC (1990) Living plant cells released from the root cap: a regulator of microbial populations in the rhizosphere. Plant Soil 129:19-27 
Hawes MC, Brigham LA, Wen F, Woo HH, Zhu Z (1998) Function of root border cells in plant health: pioneers in the rhizosphere. Annu Rev Phytopathol 36:311-327

Hawes MC, Gunawardena U, Miyasaka S, Zhao X (2000) The role of root border cells in plant defense. Trends Plant Sci 5:128-133

Hazen TC, Dubinsky EA, DeSantis TZ, Andersen GL, Piceno YM, Singh N, Jansson JK, Probst A, Borglin SE, Fortney JL, Stringfellow WT, Bill M, Conrad ME, Tom LM, Chavarria KL, Alusi TR, Lamendella R, Joyner DC, Spier C, Baelum J, Auer M, Zemla ML, Chakraborty R, Sonnenthal EL, D'haeseleer P, Holman H-YN, Osman S, Lu Z, Van Nostrand JD, Deng Y, Zhou J, Mason OU (2010) Deep-sea oil plume enriches indigenous oildegrading bacteria. Science 330:204-208. doi:10.1126/science. 1195979

Heidel AJ, Clarke JD, Antonovics J, Dong X (2004) Fitness costs of mutations affecting the systemic acquired resistance pathway in Arabidopsis thaliana. Genetics 168:2197-2206. doi:10.1534/ genetics.104.032193

Heil M (2001) The ecological concept of costs of induced systemic resistance (ISR). Eur J Plant Pathol 107:137-146

Heil M (2002) Ecological costs of induced resistance. Curr Opin Plant Biol 5:345-350. doi:10.1016/S1369-5266(02)00267-4

Heil M, Baldwin IT (2002) Fitness costs of induced resistance: emerging experimental support for a slippery concept. Trends Plant Sci 7:61-67

Hein JW, Wolfe GV, Blee KA (2008) Comparison of rhizosphere bacterial communities in Arabidopsis thaliana mutants for systemic acquired resistance. Microb Ecol 55:333-343. doi:10.1007/s00248-007-9279-1

Hiltner L (1904) Über neuere Erfahrungen und Probleme auf dem Gebiete der Bodenbakteriologie unter besonderer Berücksichtigung der Gründüngung und Brache. Arb DLG 98:59-78

Höfte M, Bakker PAHM (2007) Competition for iron and induced systemic resistance by siderophores of plant growthpromoting rhizobacteria. In: Varma A, Chincholkar SB (eds) Microbial siderophores, soil biology, vol 12. Springer, Berlin, pp 121-133

Hoitink HAJ, Boehm MJ (1999) Biocontrol within the context of soil microbial communities: a substrate-dependent phenomenon. Annu Rev Phytopathol 37:427-446

Hoitink HAJ, Madden LV, Dorrance AE (2006) Systemic resistance induced by Trichoderma spp.: interactions between the host, the pathogen, the biocontrol agent, and soil organic matter quality. Phytopathology 96:186-189. doi:10.1094/PHYTO-96-0186

Houlden A, Timms-Wilson TM, Day MJ, Bailey MJ (2008) Influence of plant developmental stage on microbial community structure and activity in the rhizosphere of three field crops. FEMS Microbiol Ecol 65:193-201. doi:10.1111/j.1574-6941.2008. 00535.x

Hughes JB, Hellmann JJ, Ricketts TH, Bohannan BJM (2001) Counting the uncountable: statistical approaches to estimating microbial diversity. Appl Environ Microbiol 67:4399-4406

Iavicoli A, Boutet E, Buchala A, Métraux JP (2003) Induced systemic resistance in Arabidopsis thaliana in response to root inoculation with Pseudomonas fluorescens CHA0. Mol Plant-Microb Interact $16: 851-858$

Janssen PH, Yates PS, Grinton BE, Taylor PM, Sait M (2002) Improved culturability of soil bacteria and isolation in pure culture of novel members of the divisions Acidobacteria, Actinobacteria, Proteobacteria, and Verrucomicrobia. Appl Environ Microbiol 68:23912396. doi:10.1128/AEM.68.5.2391-2396.2002

Jenkinson D, Ladd JN (1981) Microbial biomass in soil: measurement and turnover. In: Paul EA, Ladd JN (eds) Soil biochemistry, vol. 5. Marcel Dekker, New York, pp 417-471

Jeworutzki E, Roelfsema MRG, Anschutz U, Krol E, Elzenga TM, Felix G, Boller T, Hedrich R, Becker D (2010) Early signaling through the
Arabidopsis pattern recognition receptors FLS2 and EFR involves $\mathrm{Ca}^{2+}$-associated opening of plasma membrane anion channels. Plant J 62:367-378. doi:10.1111/j.1365-313X.2010.04155.x

Jones JDG, Dangl JL (2006) The plant immune system. Nature 444:323-329. doi:10.1038/nature05286

Jung HW, Tschaplinski TJ, Wang L, Glazebrook J, Greenberg JT (2009) Priming in systemic plant immunity. Science 324:89-91. doi:10.1126/science. 1170025

Kamilova F, Kravchenko LV, Shaposhnikov AI, Makarova N, Lugtenberg B (2006a) Effects of the tomato pathogen Fusarium oxysporum f. sp radicis-lycopersici and of the biocontrol bacterium Pseudomonas fluorescens WCS365 on the composition of organic acids and sugars in tomato root exudate. Mol Plant-Microb Interact 19:1121-1126. doi:10.1094/MPMI-191121

Kamilova F, Kravchenko LV, Shaposhnikov AI, Azarova T, Makarova N, Lugtenberg B (2006b) Organic acids, sugars, and Ltryptophane in exudates of vegetables growing on stonewool and their effects on activities of rhizosphere bacteria. Mol PlantMicrob Interact 19:250-256. doi:10.1094/MPMI-19-0250

Kent AD, Triplett EW (2002) Microbial communities and their interactions in soil and rhizosphere ecosystems. Annu Rev Microbiol 56:211-236. doi:10.1146/annurev.micro.56.012302.161120

Kinkema M, Fan W, Dong X (2000) Nuclear localization of NPR1 is required for activation of $P R$ gene expression. Plant Cell 12:2339-2350

Kloepper JW, Leong J, Teintze M, Schroth MN (1980) Enhanced plant growth by siderophores produced by plant growthpromoting rhizobacteria. Nature 286:885-886

Kloepper JW, Ryu C-M, Zhang S (2004) Induced systemic resistance and promotion of plant growth by Bacillus spp. Phytopathology 94:1259-1266

Kniskern JM, Traw MB, Bergelson J (2007) Salicylic acid and jasmonic acid signaling defense pathways reduce natural bacterial diversity on Arabidopsis thaliana. Mol Plant-Microb Interact 20:1512-1522. doi:10.1094/MPMI-20-12-1512

Knoester M, Van Loon LC, Van den Heuvel J, Hennig J, Bol JF, Linthorst HJM (1998) Ethylene-insensitive tobacco lacks nonhost resistance against soil-borne fungi. Proc Natl Acad Sci USA 95:1933-1937

Konstantinidis KT, Tiedje JM (2005) Towards a genome-based taxonomy for prokaryotes. J Bacteriol 187:6258-6264. doi:10.1128/JB.187.18.6258-6264.2005

Koornneef A, Pieterse CMJ (2008) Cross talk in defense signaling. Plant Physiol 146:839-844. doi:10.1104/pp.108.121392

Kwak Y, Bakker PAHM, Glandorf DCM, Topham J, Paulitz T, Weller DM (2009) Diversity, virulence and 2,4-diacetylphloroglucinol sensitivity of Gaeumannomyces graminis var. tritici isolates from Washington State. Phytopathology 99:472-479. doi:10.1094/ PHYTO-99-5-0472

Latour X, Corberand TS, Laguerre G, Allard F, Lemanceau P (1996) The composition of fluorescent pseudomonad populations associated with roots is influenced by plant and soil type. Appl Environ Microbiol 62:2449-2456

Lavelle P, Spain AV (2001) Soil ecology. Kluwer, Dordrecht

Lawton KA, Weymann K, Friedrich L, Vernooij B, Uknes S, Ryals J (1995) Systemic acquired resistance in Arabidopsis requires salicylic acid but not ethylene. Mol Plant-Microb Interact 8:863-870

Leeman M, Van Pelt JA, Hendrickx MJ, Scheffer RJ, Bakker PAHM, Schippers B (1995a) Biocontrol of fusarium wilt of radish in commercial greenhouse trials by seed treatment with Pseudomonas fluorescens WCS374. Phytopathology 85:1301-1305

Leeman M, Van Pelt JA, Den Ouden FM, Heinsbroek M, Bakker PAHM, Schippers B (1995b) Induction of systemic resistance by Pseudomonas fluorescens in radish cultivars differing in suscep- 
tibility to Fusarium wilt, using a novel bioassay. Eur J Plant Pathol 101:655-664

Leeman M, Den Ouden EM, Van Pelt JA, Dirkx FPM, Steijl H, Bakker PAHM, Schippers B (1996) Iron availability affects induction of systemic resistance to Fusarium wilt of radish by Pseudomonas fluorescens. Phytopathology 86:149-155

Lemanceau P, Corberand T, Gardan L, Latour X, Laguerre G, Boeufgras JM, Alabouvette C (1995) Effect of two Plant species, flax (Linum usitatissinum L.) and tomato (Lycoppersicon esculentum Mill.), on the diversity of soilborne populations of fluorescent pseudomonads. Appl Environ Microbiol 61:10041012

Little AEF, Robinson CJ, Peterson SB, Raffa KE, Handelsman J (2008) Rules of engagement: interspecies interactions that regulate microbial communities. Annu Rev Microbiol 62:375401. doi:10.1146/annurev.micro.030608.101423

Loake G, Grant M (2007) Salicylic acid in plant defence - the players and protagonists. Curr Opin Plant Biol 10:466-472. doi:10.1016/ j.pbi.2007.08.008

Loper JE, Buyer JS (1991) Siderophores in microbial interactions on plant surfaces. Mol Plant-Microb Interact 4:5-13

Loper JE, Henkels MD (1997) Availability of iron to Pseudomonas fluorescens in rhizosphere and bulk soil evaluated with an ice nucleation reporter gene. Appl Environ Microbiol 63:99-105

Loper JE, Henkels MD (1999) Utilization of heterologous siderophores enhances levels of iron available to Pseudomonas putida in the rhizosphere. Appl Environ Microbiol 65:53575363

Loyola-Vargas VM, Broeckling CD, Badri D, Vivanco JM (2007) Effect of transporters on the secretion of phytochemicals by the roots of Arabidopsis thaliana. Planta 225:301-310. doi:10.1007/ s00425-006-0349-2

Lugtenberg BJJ, Dekkers L, Bloemberg GV (2001) Molecular determinants of rhizosphere colonization by Pseudomonas. Annu Rev Phytopathol 39:461-490

Lugtenberg BJJ, Chin-A-Woeng TFC, Bloemberg GV (2002) Microbe-plant interactions: principles and mechanisms. Antonie Leeuwenhoek 81:373-383. doi:10.1023/A:1020596903142

Maier RM (2003) Biosurfactants: evolution and diversity in bacteria. Adv Appl Microbiol 52:101-121. doi:10.1016/S0065-2164(03) 01004-9

Maldonado AM, Doerner P, Dixon RA, Lamb CJ, Cameron RK (2002) A putative lipid transfer protein involved in systemic resistance signalling in Arabidopsis. Nature 419:399-403. doi:10.1038/nature00962

Mauch-Mani B, Métraux JP (1998) Salicylic acid and systemic acquired resistance to pathogen attack. Ann Bot 82:535-540

Mercado-Blanco J, Bakker PAHM (2007) Interactions between plants and beneficial Pseudomonas spp.: exploiting bacterial traits for crop protection. Antonie Leeuwenhoek 92:367-389. doi:10.1007/ s10482-007-9167-1

Métraux J-P, Signer H, Ryals J, Ward E, Wyss-Benz M, Gaudin J, Raschdorf K, Schmid E, Blum W, Inverardi B (1990) Increase in salicylic acid at the onset of systemic acquired resistance in cucumber. Science 250:1004-1006

Meziane H, Van der Sluis I, Van Loon LC, Höfte M, Bakker PAHM (2005) Determinants of Pseudomonas putida WCS358 involved in inducing systemic resistance in plants. Mol Plant Pathol 6:177-185. doi:10.1111/J.1364-3703.2004.00276.X

Micallef SA, Shiaris MP, Colón-Carmona A (2009) Influence of Arabidopsis thaliana accessions on rhizobacterial communities and natural variation in root exudates. J Exp Bot 60:1729-1742. doi:10.1093/jxb/erp053

Miyasaka SC, Hawes MC (2001) Possible role of root border cells in detection and avoidance of aluminum toxicity. Plant Physiol 125:1978-1987
Mou Z, Fan W, Dong X (2003) Inducers of plant systemic acquired resistance regulate NPR1 function through redox changes. Cell 113:935-944

Nawrath C, Métraux JP (1999) Salicylic acid induction-deficient mutants of Arabidopsis express $P R-2$ and $P R-5$ and accumulate high levels of camalexin after pathogen inoculation. Plant Cell 11:1393-1404

Neilands JB (1995) Siderophores: structure and function of microbial iron transport compounds. J Biol Chem 270:26723-26726

Newman MA, Dow JM, Molinaro A, Parrilli M (2007) Priming, induction and modulation of plant defence responses by bacterial lipopolysaccharides. J Endotoxin Res 13:69-84. doi:10.1177/ 0968051907079399

Newton AC, Fitt BDL, Atkins SD, Walters DR, Daniell TJ (2010) Pathogenesis, parasitism and mutualism in the trophic space of microbe-plant interactions. Trends Microbiol 18:365-373. doi:10.1016/j.tim.2010.06.002

Nichols D (2007) Cultivation gives context to the microbial ecologist. FEMS Microbiol Ecol 60:351-357. doi:10.1111/j.15746941.2007.00332.x

Normander B, Prosser JI (2000) Bacterial origin and community composition in the barley phytosphere as a function of habitat and presowing conditions. Appl Environ Microbiol 66:43724377

Nühse TS, Peck SC, Hirt H, Boller T (2000) Microbial elicitors induce activation and dual phosphorylation of the Arabidopsis thaliana MAPK 6. J Biol Chem 275:7521-7526

Oldroyd GED, Downie JM (2008) Coordinating nodule morphogenesis with rhizobial infection in legumes. Annu Rev Plant Biol 59:519-546. doi:10.1146/annurev.arplant.59.032607.092839

Ongena M, Jourdan E, Adam A, Paquot M, Brans A, Joris B, Arpigny JL, Thonart P (2007) Surfactin and fengycin lipopeptides of Bacillus subtilis as elicitors of induced systemic resistance in plants. Environ Microbiol 9:1084-1090. doi:10.1111/j.14622920.2006.01202.x

Park S-W, Kaimoyo E, Kumar D, Mosher S, Klessig DF (2007) Methyl salicylate is a critical mobile signal for plant systemic acquired resistance. Science 318:113-116. doi:10.1126/science.1147113

Persello-Cartieaux F, Nussaume L, Robaglia C (2003) Tales from the underground: molecular plant-rhizobacteria interactions. Plant Cell Environ 26:189-199. doi:10.1046/j.1365-3040.2003.00956.x

Pieterse CM, Van Loon LC (2004) NPR1: the spider in the web of induced resistance signaling pathways. Curr Opin Plant Biol 7:456-464. doi:10.1016/j.pbi.2004.05.006

Pieterse CMJ, Van Wees SCM, Hoffland E, Van Pelt JA, Van Loon LC (1996) Systemic resistance in Arabidopsis induced by biocontrol bacteria is independent of salicylic acid accumulation and pathogenesis-related gene expression. Plant Cell 8:1225-1237

Pieterse CMJ, Van Wees SCM, Van Pelt JA, Knoester M, Laan R, Gerrits N, Weisbeek PJ, Van Loon LC (1998) A novel signaling pathway controlling induced systemic resistance in Arabidopsis. Plant Cell 10:1571-1580

Pieterse CMJ, Van Pelt JA, Ton J, Parchmann S, Mueller MJ, Buchala AJ, Métraux J-P, Van Loon LC (2000) Rhizobacteria-mediated induced systemic resistance (ISR) in Arabidopsis requires sensitivity to jasmonate and ethylene but is not accompanied by an increase in their production. Physiol Mol Plant Pathol 57:123-134

Pieterse CMJ, Van Wees SCM, Ton J, Van Pelt JA, Van Loon LC (2002) Signalling in rhizobacteria-induced systemic resistance in Arabidopsis thaliana. Plant Biol 4:535-544

Pieterse CMJ, Leon-Reyes A, Van der Ent S, Van Wees SCM (2009) Networking by small-molecule hormones in plant immunity. Nat Chem Biol 5:308-316. doi:10.1038/nchembio.164

Ping L, Boland W (2004) Signals from the underground: bacterial volatiles promote growth in Arabidopsis. Trends Plant Sci 9:263266. doi:10.1016/j.tplants.2004.04.008 
Postma J, Van Veen JA (1990) Habitable pore space and survival of Rhizobium leguminosarum biovar trifolii introduced into soil. Microb Ecol 19:149-161

Pozo MJ, Van Loon LC, Pieterse CMJ (2004) Jasmonates - signals in plant-microbe interactions. J Plant Growth Regul 23:211-222. doi:10.1007/s00344-004-0031-5

Pozo MJ, Van Der Ent S, Van Loon LC, Pieterse CMJ (2008) Transcription factor MYC2 is involved in priming for enhanced defense during rhizobacteria-induced systemic resistance in Arabidopsis thaliana. New Phytol 180:511-523. doi:10.1111/ j.1469-8137.2008.02578.x

Raaijmakers JM, Leeman M, Van Oorschot MMP, Van der Sluis I, Schippers B, Bakker PAHM (1995) Dose-response relationships in biological control of Fusarium wilt of radish by Pseudomonas spp. Phytopathology 85:1075-1081

Raaijmakers JM, Vlami M, de Souza JT (2002) Antibiotic production by bacterial biocontrol agents. Antonie Leeuwenhoek 81:537547. doi:10.1023/A:1020501420831

Raaijmakers JM, De Bruijn I, De Kock MJD (2006) Cyclic lipopeptide production by plant-associated Pseudomonas spp.: diversity, activity, biosynthesis, and regulation. Mol PlantMicrob Interact 19:699-710. doi:10.1094/MPMI-19-0699

Raaijmakers JM, Paulitz TC, Steinberg C, Alabouvette C, MoënneLoccoz Y (2009) The rhizosphere: a playground and battlefield for soilborne pathogens and beneficial microorganisms. Plant Soil 321:341-361. doi:10.1007/s11104-008-9568-6

Ran LX, Van Loon LC, Bakker PAHM (2005) No role for bacterially produced salicylic acid in rhizobacterial induction of systemic resistance in Arabidopsis. Phytopathology 95:1349-1355. doi:10.1094/PHYTO-95-1349

Ranjard L, Poly F, Combrisson J, Richaume A, Gourbière F, Thioulouse J, Nazaret S (2000) Heterogeneous cell density and genetic structure of bacterial pools associated with various soil microenvironments as determined by enumeration and DNA fingerprinting approach (RISA). Microb Ecol 39:263272

Robin A, Mougel C, Siblot S, Vansuyt G, Mazurier S, Lemanceau P (2006) Effect of ferritin overexpression in tobacco on the structure of bacterial and pseudomonad communities associated with the roots. FEMS Microbiol Ecol 58:492-502. doi:10.1111/ j.1574-6941.2006.00174.x

Robin A, Mazurier S, Mougel C, Vansuyt G, Corberand T, Meyer J-M, Lemanceau P (2007) Diversity of root-associated fluorescent pseudomonads as affected by ferritin overexpression in tobacco. Environ Microbiol 9:1724-1737. doi:10.1111/j.14622920.2007.01290.x

Roitsch T, Balibrea ME, Hofmann M, Proels R, Sinha AK (2003) Extracellular invertase: key metabolic enzyme and PR protein. J Exp Bot 54:513-524. doi:10.1093/jxb/erg050

Rooney DC, Clipson NJW (2009) Phosphate addition and plant species alters microbial community structure in acidic upland grassland soil. Microb Ecol 57:4-13. doi:10.1007/s00248-008-9399-2

Ross AF (1961) Systemic acquired resistance induced by localized virus infections in plants. Virology 14:340-358

Rosselló-Mora R, Amann R (2001) The species concept for prokaryotes. FEMS Microbiol Rev 25:39-67

Rudrappa T, Kirk J, Czymmek PW, Paré PW, Bais HP (2008) Rootsecreted malic acid recruits beneficial soil bacteria. Plant Physiol 148:1547-1556. doi:10.1104/pp.108.127613

Ryu C-M, Farag MA, Hu C-H, Reddy MS, Wei H-X, Paré PW, Kloepper JW (2003) Bacterial volatiles promote growth in Arabidopsis. Proc Natl Acad Sci USA 100:4927-4932. doi:10.1073/pnas.0730845100

Schuhegger R, Ihring A, Gantner S, Bahnweg G, Knappe C, Vogg G, Hutzler P, Schmid M, Van Breusegem F, Eberl L, Hartmann A, Langebartels C (2006) Induction of systemic resistance in tomato by $N$-acyl-L-homoserine lactone-producing rhizosphere bacteria. Plant Cell Environ 29:909-918. doi:10.1111/j.1365-3040.2005. 01471.x

Schumann GL, D'Arcy CJ (2006) Essential plant pathology. The American Phytopathological Society, St. Paul

Segarra G, Van der Ent S, Trillas I, Pieterse CMJ (2009) MYB72, a node of convergence in induced systemic resistance triggered by a fungal and a bacterial beneficial microbe. Plant Biol 11:90-96. doi:10.1111/j.1438-8677.2008.00162.x

Seskar M, Shulaev V, Raskin I (1998) Endogenous methyl salicylate in pathogen-inoculated tobacco plants. Plant Physiol 116:387392

Sessitsch A, Weilharter A, Gerzabek MH, Kirchmann H, Kandeler E (2001) Microbial population structures in soil particle size fractions of a long-term fertilizer field experiment. Appl Environ Microbiol 67:4215-4224

Singh BK, Millard P, Whiteley AS, Murrell JC (2004) Unravelling rhizosphere-microbial interactions: opportunities and limitations. Trends Microbiol 12:386-393. doi:10.1016/j.tim.2004.06.008

Smalla K, Wieland G, Buchner A, Zock A, Parzy J, Kaiser S, Roskot N, Heuer H, Berg G (2001) Bulk and rhizosphere soil bacterial communities studied by denaturing gradient gel electrophoresis: plant-dependent enrichment and seasonal shifts revealed. Appl Environ Microbiol 67:4742-4751

Sonnemann I, Finkhaeuser K, Wolters V (2002) Does induced resistance in plants affect the belowground community? Appl Soil Ecol 21:179-185

Steenhoudt O, Vanderleyden J (2000) Azospirillum, a free-living nitrogenfixing bacterium closely associated with grasses: genetic, biochemical and ecological aspects. FEMS Microbiol Rev 24:487-506

Sticher L, Mauch-Mani B, Métraux J-P (1997) Systemic acquired resistance. Annu Rev Phytopathol 35:235-270

Thomma BPHJ, Penninckx IAMA, Broekaert WF, Cammue BPA (2001) The complexity of disease signaling in Arabidopsis. Curr Opin Immunol 13:63-68

Timms-Wilson TM, Kilshaw K, Bailey MJ (2004) Risk assessment for engineered bacteria used in biocontrol of fungal disease in agricultural crops. Plant Soil 266:57-67

Ton J, Pieterse CMJ, Van Loon LC (1999) Identification of a locus in Arabidopsis controlling both the expression of rhizobacteriamediated induced systemic resistance (ISR) and basal resistance against Pseudomonas syringae pv. tomato. Mol Plant-Microb Interact 12:911-918

Ton J, Davison S, Van Wees SCM, Van Loon LC, Pieterse CMJ (2001) The Arabidopsis ISR1 locus controlling rhizobacteriamediated induced systemic resistance is involved in ethylene signaling. Plant Physiol 125:652-661

Ton J, Van Pelt JA, Van Loon LC, Pieterse CMJ (2002) Differential effectiveness of salicylate-dependent and jasmonate/ethylenedependent induced resistance in Arabidopsis. Mol Plant-Microb Interact 15:27-34

Ton J, Pieterse CMJ, Van Loon LC (2006) Multigenic and induced systemic resistance in plants. In: Tuzun S, Bent E (eds) Multigenic and induced systemic resistance in plants. Springer, New York, pp 197-224

Torsvik V, Øvreås L (2002) Microbial diversity and function in soil: from genes to ecosystems. Curr Opin Microbiol 5:240-245

Torsvik V, Goksøyr J, Daae FL (1990) High diversity in DNA of soil bacteria. Appl Environ Microbiol 56:782-787

Tran H, Ficke A, Asiimwe T, Höfte M, Raaijmakers JM (2007) Role of the cyclic lipopeptide massetolide A in biological control of Phytophthora infestans and in colonization of tomato plants by Pseudomonas fluorescens. New Phytol 175:731-742. doi:10.1111/j.1469-8137.2007.02138.x

Truman W, Bennett MH, Kubigsteltig I, Turnbull C, Grant M (2007) Arabidopsis systemic immunity uses conserved defense signaling 
pathways and is mediated by jasmonates. Proc Natl Acad Sci USA 104:1075-1080. doi:10.1073 pnas.0605423104

Uknes S, Mauch-Mani B, Moyer M, Potter S, Williams S, Dincher S, Chandler D, Slusarenko A, Ward E, Ryals J (1992) Acquired resistance in Arabidopsis. Plant Cell 4:645-656

Uren NC (2000) Types, amount, and possible functions of compounds released into the rhizosphere by soil-grown plants. In: Pinton R, Varanini Z, Nannipieri P (eds) The rhizosphere: biochemistry and organic substances at the soil-plant interface. Marcel Dekker, New York, pp 19-40

Van den Burg HA, Takken FLW (2009) Does chromatin remodeling mark systemic acquired resistance? Trends Plant Sci 14:286-294. doi:10.1016/j.tplants.2009.02.003

Van der Ent S, Verhagen BWM, Van Doorn R, Bakke D, Verlaan MG, Pel MJC, Joosten RG, Proveniers MCG, Van Loon LC, Ton J, Pieterse CMJ (2008) MYB72 is required in early signaling steps of rhizobacteria-induced systemic resistance in Arabidopsis. Plant Physiol 146:1293-1304. doi:10.1104/ pp.107.113829

Van der Ent S, Van Hulten M, Pozo MJ, Czechowski T, Udvardi MK, Pieterse CMJ, Ton J (2009) Priming of plant innate immunity by rhizobacteria and $\beta$-aminobutyric acid: differences and similarities in regulation. New Phytol 138:419-431. doi:10.1111/j.14698137.2009.02851.x

Van Hulten M, Pelser M, Van Loon LC, Pieterse CMJ, Ton J (2006) Costs and benefits of priming for defense in Arabidopsis. Proc Natl Acad Sci USA 103:5602-5607. doi:10.1073 pnas.0510213103

Van Loon LC (1997) Induced resistance and the role of pathogenesisrelated proteins. Eur J Plant Pathol 103:753-765

Van Loon LC (2007) Plant responses to plant growth-promoting rhizobacteria. Eur J Plant Pathol 119:243-254. doi:10.1007/ s10658-007-9165-1

Van Loon LC, Bakker PAHM (2003) Signaling in rhizobacteria-plant interactions. In: De Krron H, Visser EJW (eds) Root ecology. Springer, Berlin, pp 297-330

Van Loon LC, Bakker PAHM, Pieterse CMJ (1998) Systemic resistance induced by rhizosphere bacteria. Annu Rev Phytopathol $36: 453-483$

Van Loon LC, Geraats BPJ, Linthorst HJM (2006) Ethylene as a modulator of disease resistance in plants. Trends Plant Sci 11:184-191. doi:10.1016/j.tplants.2006.02.005

Van Oosten VR, Bodenhausen N, Reymond P, Van Pelt JA, Van Loon LC, Dicke M, Pieterse CMJ (2008) Differential effectiveness of microbially induced resistance against herbivorous insects in Arabidopsis. Mol Plant-Microb Interact 21:919-930. doi:10.1094/ MPMI-21-7-0919

Van Peer R, Niemann GJ, Schippers B (1991) Induced resistance and phytoalexin accumulation in biological control of Fusarium wilt of carnation by Pseudomonas sp. strain WCS417r. Phytopathology 81:728-734

Van Wees SCM, Pieterse CMJ, Trijssenaar A, Van 't Westende YA, Hartog F, Van Loon LC (1997) Differential induction of systemic resistance in Arabidopsis by biocontrol bacteria. Mol PlantMicrob Interact 10:716-724

Van Wees SCM, Luijendijk M, Smoorenburg I, Van Loon LC, Pieterse CMJ (1999) Rhizobacteria-mediated induced systemic resistance (ISR) in Arabidopsis is not associated with a direct effect on expression of known defense-related genes but stimulates the expression of the jasmonate-inducible gene Atvsp upon challenge. Plant Mol Biol 41:537-549

Van Wees SCM, Van der Ent S, Pieterse CMJ (2008) Plant immune responses triggered by beneficial microbes. Curr Opin Plant Biol 11:443-448. doi:10.1016/j.pbi.2008.05.005

Van Wuytswinkel O, Vansuyt G, Grignon N, Fourcroy P, Briat J-F (1999) Iron homeostasis alteration in transgenic tobacco overexpressing ferritin. Plant J 17:93-97
Verhagen BWM, Glazebrook J, Zhu T, Chang H-S, Van Loon LC, Pieterse CMJ (2004) The transcriptome of rhizobacteria-induced systemic resistance in Arabidopsis. Mol Plant-Microb Interact 17:895-908

Vernooij B, Friedrich L, Morse A, Reist R, Kolditz-Jawhar R, Ward E, Uknes S, Kessmann H, Ryals J (1994) Salicylic acid is not the translocated signal responsible for inducing systemic acquired resistance but is required in signal transduction. Plant Cell 6:959-965

Vicré M, Santaella C, Blanchet S, Gateau A, Driouich A (2005) Root border-like cells of Arabidopsis. Microscopical characterization and role in the interaction with rhizobacteria. Plant Physiol 138:998-1008. doi:10.1104/pp.104.051813

Viebahn M, Glandorf DCM, Ouwens TWM, Smit E, Leeflang P, Wernars K, Thomashow LS, Van Loon LC, Bakker PAHM (2003) Repeated introduction of genetically modified Pseudomonas putida WCS358r without intensified effects on the indigenous microflora of field-grown wheat. Appl Environ Microbiol 69:3110-3118. doi:10.1128/AEM.69.6.3110-3118.2003

Viebahn M, Veenman C, Wernars K, Smit E, Van Loon LC, Bakker PAHM (2005) Assessment of differences in ascomycete communities in the rhizosphere of field-grown wheat and potato. FEMS Microbiol Ecol 53:245-253. doi:10.1016/j.femsec.2004.12.014

Viebahn M, Wernars K, Smit E, van Loon LC, DeSantis TZ, Andersen GL, Bakker PAHM (2006) Microbial diversity in wheat rhizosphere as affected by genetically modified Pseudomonas putida WCS358r. IOBC/WPRS Bull 29:167-172

Vlot AC, Klessig DF, Park S-W (2008) Systemic acquired resistance: the elusive signal(s). Curr Opin Plant Biol 11:436-442. doi:10.1016/j.pbi.2008.05.003

Walker TS, Bais HP, Halligan KM, Stermitz FR, Vivanco JM (2003) Metabolic profiling of root exudates of Arabidopsis thaliana. J Agric Food Chem 51:2548-2554. doi:10.1021/jf021166h

Walters D, Heil M (2007) Costs and trade-offs associated with induced resistance. Physiol Mol Plant Pathol 71:3-17. doi:10.1016/j.pmpp.2007.09.008

Wang D, Weaver ND, Kesarwani M, Dong X (2005) Induction of protein secretory pathway is required for systemic acquired resistance. Science 308:1036-1040. doi:10.1126/science. 1108791

Wang D, Amornsiripanitch N, Dong X (2006) A genomic approach to identify regulatory nodes in the transcriptional network of systemic acquired resistance in plants. PLoS Pathog 2:10421050. doi:10.1371/journal.ppat.0020123

Wei G, Kloepper JW, Tuzun S (1991) Induction of systemic resistance of cucumber to Coletotrichum orbiculare by selected strains of plant growth-promoting rhizobacteria. Phytopathology 81:1508-1512

Weller DM (1988) Biological control of soilborne plant-pathogens in the rhizosphere with bacteria. Annu Rev Phytopathol 26:379-407

Weller DM (2007) Pseudomonas biocontrol agents of soilborne pathogens: looking back over 30 years. Phytopathology 97:250-256. doi:10.1094/PHYTO-97-2-0250

Weller DM, Raaijmakers JM, McSpadden Gardener BB, Thomashow LS (2002) Microbial populations responsible for specific soil suppressiveness to plant pathogens. Annu Rev Phytopathol 40:309-348. doi:10.1146/annurev.phyto.40.030402.110010

Whipps JM (2001) Microbial interactions and biocontrol in the rhizosphere. J Exp Bot 52:487-511

Whitman WB, Coleman DC, Wiebe WJ (1998) Prokaryotes: the unseen majority. Proc Natl Acad Sci USA 95:6578-6583

Yang J, Kloepper JW, Ryu C-M (2009) Rhizosphere bacteria help plants tolerate abiotic stress. Trends Plant Sci 14:1-4. doi:10.1016/j.tplants.2008.10.004

Zehnder GW, Murphy JF, Sikora EJ, Kloepper JW (2001) Application of rhizobacteria for induced resistance. Eur J Plant Pathol 107:39-50

Zhang Y, Fan W, Kinkema M, Li X, Dong X (1999) Interaction of NPR1 with basic leucine zipper protein transcription 
factors that bind sequences required for salicylic acid induction of the $P R-1$ gene. Proc Natl Acad Sci USA 96: $6523-6528$

Zhou N, Tootle TL, Tsui F, Klessig DF, Glazebrook J (1998) PAD4 functions upstream from salicylic acid to control defense responses in Arabidopsis. Plant Cell 10:1021-1030

Zhuang X, Chen J, Shim H, Bai Z (2007) New advances in plant growth-promoting rhizobacteria for bioremediation. Environ Int 33:406-413. doi:10.1016/j.envint.2006.12.005
Zipfel C (2008) Pattern-recognition receptors in plant innate immunity. Curr Opin Immunol 20:10-16. doi:10.1016/j.coi.2007.11.003

Zipfel C, Robatzek S, Navarro L, Oakeley EJ, Jones JDG, Felix G, Boller T (2004) Bacterial disease resistance in Arabidopsis through flagellin perception. Nature 428:764-767. doi:10.1038/nature02485

Zipfel C, Kunze G, Chinchilla D, Caniard A, Jones JDG, Boller T, Felix G (2006) Perception of the bacterial PAMP EF-Tu by the receptor EFR restricts Agrobacterium-mediated transformation. Cell 125:749-760. doi:10.1016/j.cell.2006.03.037 